\title{
3D static reservoir modelling to evaluate petroleum potential of Goru C-Interval sands in Sawan Gas Field, Pakistan
}

\author{
${ }^{1}$ Department of Earth Sciences, Quaid-i-Azam University, 45320, Islamabad, Pakistan \\ ${ }^{2}$ Department of Geophysics, Arab Company for Laboratories and Soil, 70156, Al Khobar branch, Kingdom of Saudi Arabia; *Corresponding \\ author,E-mail:afarid@aces-int.com,asam.farid@gmail.com
}

(Received: April 10, 2021; Revised accepted: September 13, 2021)

https://doi.org/10.18814/epiiugs/2021/021028

This study is aimed at building a 3D static model of the C-Interval horizon within the Lower Goru Formation of the Sawan gas field, Pakistan. The C-Interval horizon is a proven gas reservoir with considerable potential for further development. Sequence stratigraphic interpretation reveals that C-Interval horizon was deposited under transgressive-regressive conditions, with forced regression resulting in deposition of sand bodies in a deltaic environment. Well logs and core analysis reveal different lithological facies. Thin interbedded shales induced extreme heterogeneity in C-Interval reservoir properties. Sequential Indicator Simulation (SIS) and Sequential Gaussian Simulation (SGS) have been applied to spatially map the heterogeneities of the reservoir properties such as water saturation $\left(S_{w}\right)$, porosity $(\varphi)$, facies, etc. The models indicate thick reservoir quality sand facies are present in the northeastern half with high effective porosity $\left(\varphi_{e}\right)$ being consistent with the high sand content near the paleo-coast line. However, the shale content $\left(V_{s h}\right)$ increases towards the southwestern half consistent with more basinward settings. The lithologies in the southwestern half exhibit low $\varphi_{e}$ with an increase in $S_{w}$. The techniques utilized in this study have implications for other producing hydrocarbon fields with complex reservoir properties and similar geological settings.

\section{Introduction}

The world's growing population will see increasing demand for energy resources in order to sustain an improved quality of life. Advancements in computational technology has resulted in increasing success for the search of hydrocarbon resources within geological basins (Adeoti et al., 2014; Osinowo et al., 2018). Three-dimensional reservoir modelling is now more commonly performed for exploitation of hydrocarbon fields (Godwill and Waburoko, 2016; Chongwain et al., 2019) and has been extensively applied in the hydrocarbon industry for improved visualization of reservoir properties (Patrick et al., 2002; Singh et al., 2013; Soleimani et al., 2016; Abeed et al., 2019). Utilizing a time and cost-effective solution in the determination and visualization of reservoir properties is an essential requirement of reservoir studies. In order to develop or explore a new hydrocarbon field, detailed reservoir modelling is required in addition to conventional studies such as structure, stratigraphy and formation evaluation (Benetatos et al., 2010; Adelu et al., 2019).

The stratigraphy and structure of the reservoir should be well understood in order to develop an accurate and detailed reservoir model. High resolution seismic (HRS) reflection data provides an effective approach in delineating the structure, stratigraphy and depositional setting of the reservoir (Ahmed et al., 2004; Zeng and Hentz, 2004; Li et al., 2017). Delineation of the depositional setting of the formation is required as reservoir properties such as porosity $(\varphi)$, permeability $(\delta)$, shale content $\left(V_{s h}\right)$ and water saturation $\left(S_{w}\right)$ depend upon lithologies present (Jafarzadeh et al., 2019). Hence the type of lithology and its depositional setting help to understand the variation in petrophysical properties (Haldorsen and Damsleth, 1990). Geophysical well logs such as gamma ray (GR) and self potential in addition to reservoir core logs are key to interpret the lithological variation in the reservoir. Geophysical logs are then compared with corresponding core logs (where available) to identify relationships between measured logs and actual lithologies. In addition, geophysical logs provide the reservoir parameters such as $\varphi, \delta$ and $S_{w}$ at well locations (Baouche et al., 2020).

Drilling a large number of wells for the calculation of formation properties is prohibitively expensive in both time and cost. A threedimensional (3D) HRS survey provides an effective approach to mapping variations of properties in clastic reservoirs (Zhao et al., 2020). Seismic sequence stratigraphy techniques aid in establishing the depositional setting of a particular formation for a basin while assisting the prediction of lithologies (Vail et al., 1987; Ahmed et al., 2004; Munir et al., 2011). Key lithologic horizons identified on seismic reflection data are correlated to well data either by generating synthetic seismograms, check shot surveys or by a vertical seismic profiling (Cubizolle et al., 2015; Ali and Farid, 2016; Wu and Caumon, 2017). Utilizing the results of studies from well data to predict and map reservoir properties over large areas can provide a guide for the reservoir modelling procedure (Ali et al., 2018, 2019).

A reservoir model (both static and dynamic) is a digital depiction of 
subsurface content and conditions (Doyen, 2007; Visser and Viota, 2017). Modelling improves the subsurface reservoir characterization through integration of all geophysical (seismic, well logs), geological (well cores, lithologies), petrophysical and production data (Mode and Anyiam, 2007; Aizebeokhai and Olayinka, 2011; Adelu et al., 2016). The development of an existing hydrocarbon field requires a 3D reservoir model be constructed typically in two phases, i.e., first construct a static model which describe the geological architecture of the reservoir and second, build a dynamic model to describe the fluid distribution within the reservoir (Visser and Viota, 2017; Adelu et al., 2019). Reservoir modelling can be calibrated through historical field data (including geophysical, geological, petrophysical and production data) to describe the future development of the reservoir.

The Lower Indus Basin holds a significant economic position due to its existing hydrocarbon reserves including many oil and gas fields (Quadri, 1986; Zaigham and Mallick, 2000). The Sawan gas field lies on the Jacobabad-Khairpur High (as highlighted in Fig. 1). Currently, it is producing from the sandstone (C-Interval) of the Lower Goru Formation that accumulates several commercial hydrocarbons resources (Ahmed et al., 2004; Berger et al., 2009; Yasin et al., 2019). Most recent studies are focused on evaluating the reservoir properties of the Lower Goru Formation (Anwer et al., 2017; Azeem et al., 2017; Toqeer and Ali, 2017; Ali et al., 2018).

The current study aims to develop a static model of the C-Interval of the Lower Goru Formation utilizing 3D seismic reflection data and techniques with existing well data (geophysical logs, core description and formation tops). Emphasis is on evaluating the depositional settings, identifying the prolific sand zones and determining the properties

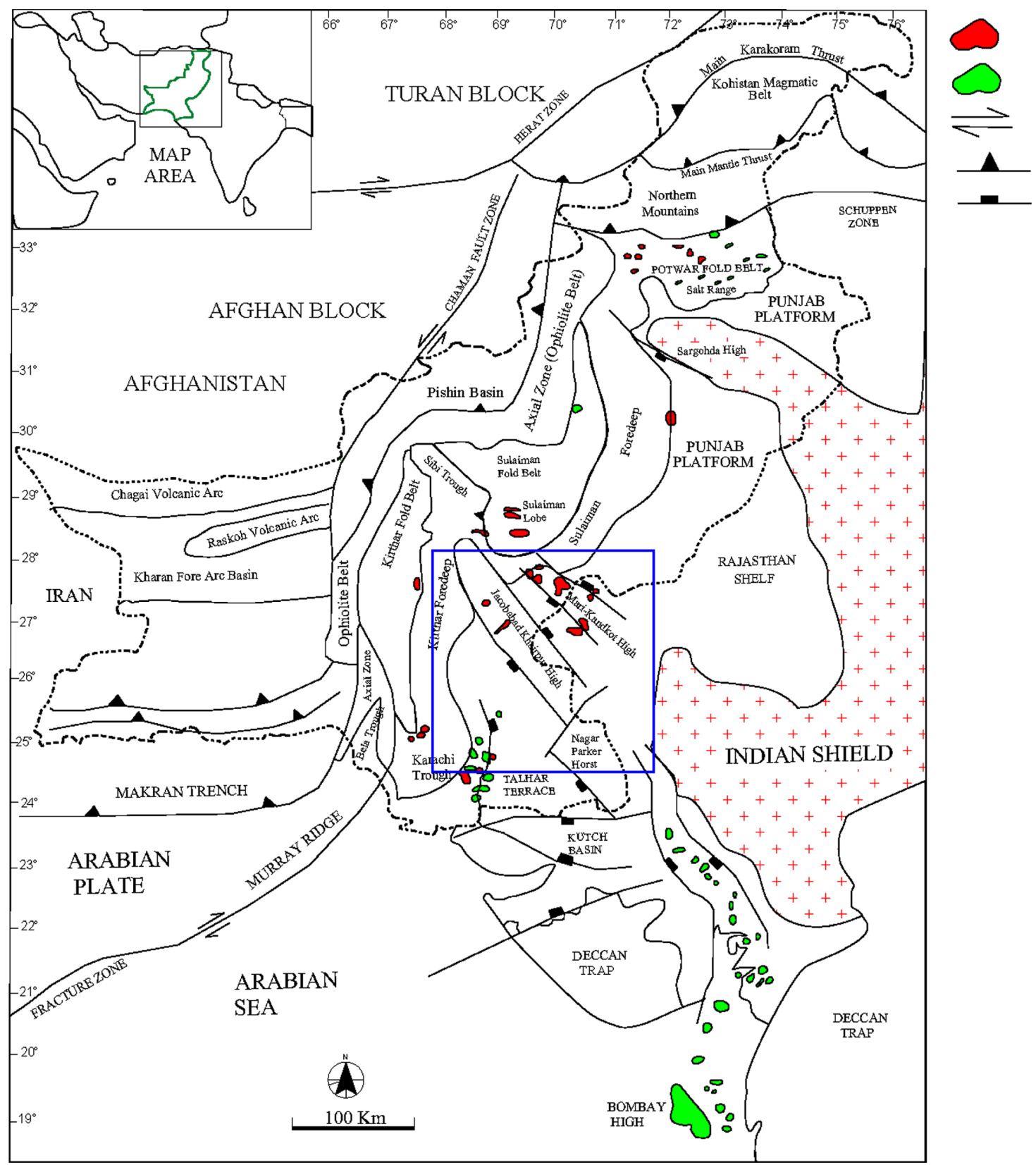

GAS FIELD

OIL FIELD

TRANSFORM FAULT

THRUST FAULT

NORMAL FAULT

Figure 1. Regional location of Sawan gas field on Jacobabad-Khairpur High area in Pakistan (modified after Kadri, 1995) as highlighted by blue square. 
of C-Interval in a 3D domain. The C-Interval horizon was identified by establishing a time-depth (T-D) relationship between the wells and 3D seismic data. The seismic horizons were mapped and a structural model was established. Key facies and formation property interpretation from the wells acted as a constraint for 3D seismic mapping. Poststack seismic inversion identified further potential prospect zones within the reservoir.

\section{Geological Settings}

The study area lies within the Sukkur Rift zone along the south eastern margin of Jacobabad-Khairpur High (Kadri, 1995; Kazmi and Jan, 1997; Zaigham and Mallick, 2000; Ahmed et al., 2004) as shown in Fig. 2. Geologically, the Punjab Platform lies towards the northeast of the study area, the Sulaiman Fold Belt to the north and northwest, the Kirthar Fold Belt towards the west and the Rajasthan Shelf and Indian Shield to the east (Kadri, 1995) as shown in Figs. 1 and 2. The sedimentary succession over the basement is approximately $4000 \mathrm{~m}$ thick within the Sukkur Rift Zone with significant amounts of hydrocarbons trapped within the Mesozoic and Tertiary formations (Kazmi and Jan, 1997). The structure and stratigraphy of the area are controlled by three major tectonic events: uplift and erosion of stratum during the Late Cretaceous, Late Paleocene tear faulting, and uplift of the Jacobabad-Khairpur high in the Late Tertiary (Ahmed et al., 2013; Azeem et al., 2016).

The first uplifting episode happened in Late Cretaceous time near to the Cretaceous-Tertiary (K-T) boundary, which was evidenced by thinning of the Ranikot Formation towards paleo highs (Ahmed et al., 2004). The occurrence of volcanic rocks which include basaltic flows, tuffs and volcanic boulder conglomerates in the lower part of the Bibai
Formation further west of the study area suggest the existence of volcanism due to the collision of the Indian and Eurasian plates in the Late Cretaceous. The unconformities existing within the Late Cretaceous sequences indicate the variable tectonic and stratigraphic conditions of the basin (Kazmi and Jan, 1997). Later, anticlockwise rotation of the Indian plate and its collision with the Eurasian plate induced wrench faulting (Zaigham and Mallick, 2000; Ahmed et al., 2004). Basement induced NNW to SSE wrench faults cut the whole sedimentary section till Cretaceous (Kazmi, 1979; Kazmi and Rana, 1982). These faults form as a single rooted system within the basement and changes character to a multiple fault system (making negative flower structures) near the Upper Goru formation until terminating against the tertiary unconformity (Azeem et al., 2018). Uplifting of JacobabadKhairpur high happened in the Late Tertiary which controlled the sedimentation of the reservoir units of Lower Goru Formation (Berger et al., 2009; Azeem et al., 2016; Khan and Khan, 2018). The tectonic activity of the western axial belts formed the foreland bulges which initiated the formations of traps within the Lower Indus Basin (Ahmed et al., 2013).

The stratigraphic succession of the study area is presented in Fig. 3. The oldest rocks belong to the Wulgai Formation which is the only exposed Triassic strata in the region. This formation was deposited in an open marine environment and consists of limestone. The Jurassic rocks in the region include the thick clastic sequences of Shirinab Formation (Kazmi and Jan, 1997). The deposition of thick-bedded Chiltan Limestone followed the deposition of the Shirinab Formation with a conformable contact (Kazmi and Jan, 1997). An unconformity separates the Chiltan Limestone and the Cretaceous Sembar Formation (Williams, 1959; Kazmi and Jan, 1997). Sembar Formation consist of black shale, sandstone and nodular limestone (Quadri and Shuaib, 1986; Kadri, 1995). Goru Formation follows the Sembar Formation and is comprised of
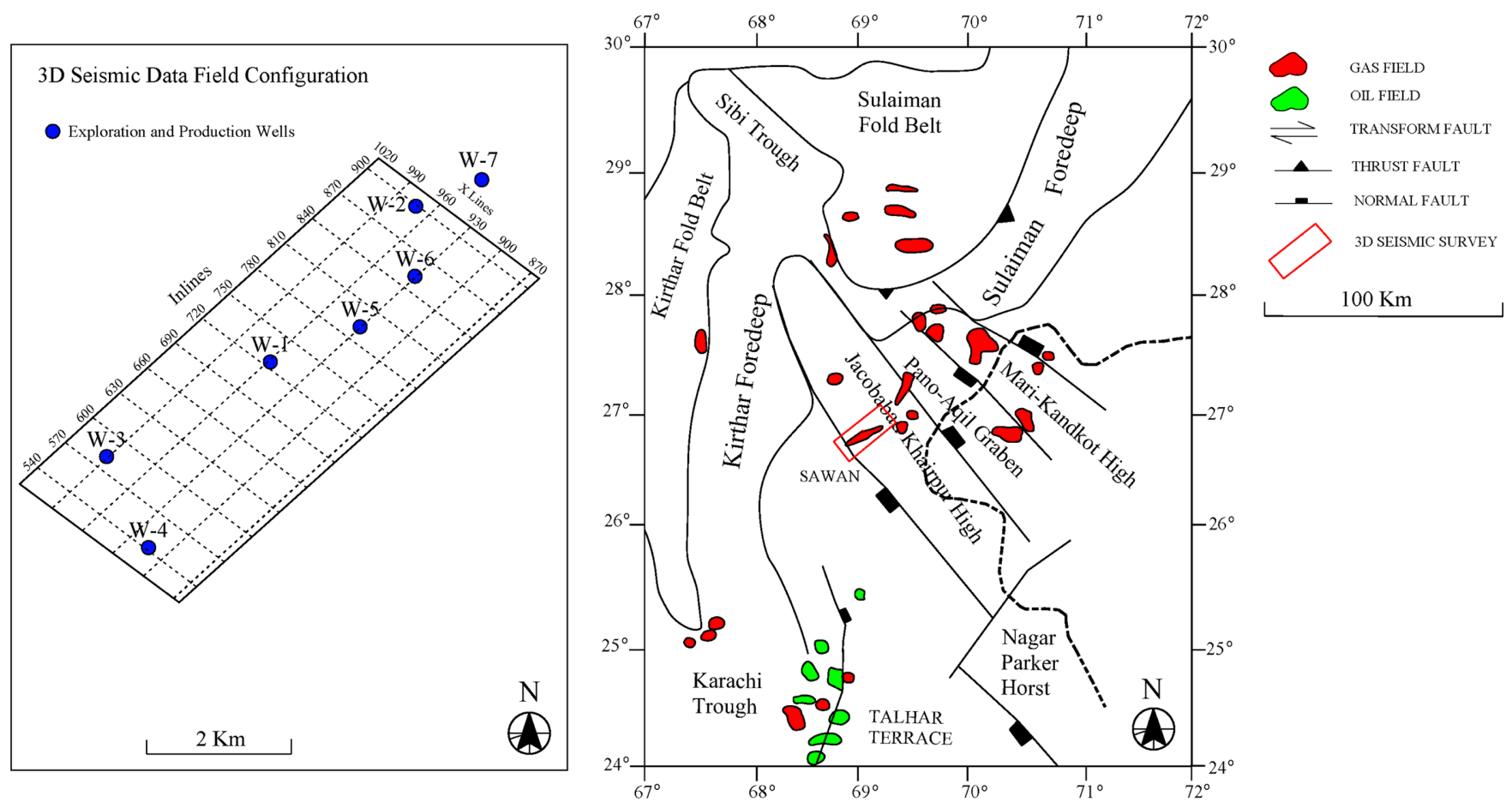

Figure 2. Basemap of study area including geological structure, locations of oil and gas fields, $3 D$ seismic boundary and well locations (modified after Kadri, 1995). 


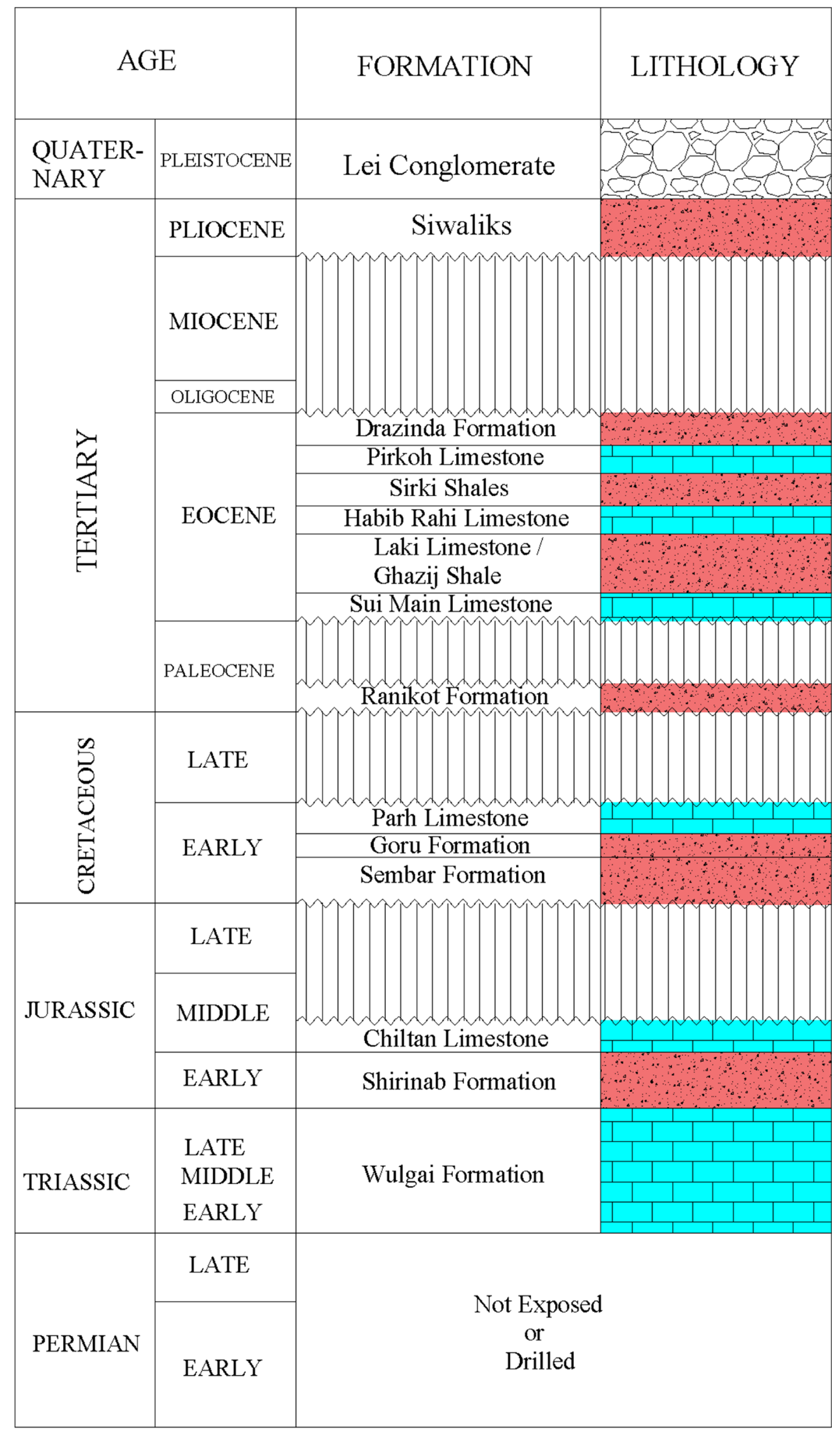

Clastic Rocks

Carbonate Rocks

Figure 3. Stratigraphy of the study area developed from well data and modified after Kadri (1995). 
limestone, shale, sandstone and siltstone. Goru Formation is divided into Upper and Lower Goru Formations depending on lithological settings. Lower Goru Formation consists of interlayered sandstone and shale horizons (Krois et al., 1998). The sandstone horizons are divided into AInterval, B-Interval, C-Interval and D-Interval (Ahmed et al., 2004; Berger et al., 2009; Munir et al., 2011; Yasin, 2019).

\section{Data Sets and Methods}

The details of seismic and well data sets are presented in Table 1. The current study makes use of 3D seismic reflection data which was acquired and processed using standard industry processing algorithms. The post stack seismic reflection 3D cube represents a subsurface image of $4.5 \mathrm{sec}$ two-way time. Complete data sets of six wells from the Sawan gas field including wireline logs, formation tops, lithological information were available for the current study. The data sets were georeferenced in Universal Transverse Mercator (UTM-43N) projection system.

The work flow for the static modelling of the C-Interval horizon is presented in Fig. 4. This process includes horizon identification, seismic stratigraphy, petrophysical interpretation, sequential gaussian and indicator simulations, facies and property modelling.

In order to delineate the sand horizons of Lower Goru Formation, well to seismic tie was performed by generating synthetic seismograms with the help of density and sonic logs. The seismic wavelet was extracted from the 3D seismic cube which was later convolved with the reflectivity series generated by density and sonic logs from W-5. The resulting synthetic seismogram was correlated for coherency with the seismic data to identify the major subsurface horizons in addition to the sands of Lower Goru Formation as shown in Fig. 5.

\section{Reservoir Parameters and Well Correlation}

The reservoirs parameters have been estimated through the analysis of well logs. The calculated parameters include the volume of shale $\left(V_{s h}\right)$ effective porosity $\left(\varphi_{e}\right)$ and water saturation $\left(S_{w}\right)$. Initially, facies were identified at the well locations referencing borehole logs predominantly using GR logs calibrated into GR zones. GR $>80$ API were used to identify 'Shale Facies', GR 50 to 80 API correspond to 'Shaly Sand Facies' and GR $<50$ API identifies the 'Sand Facies'. The interpreted lithologies (facies) are presented in Fig. 6.
The $\varphi_{e}$ was calculated using the formula presented by Asquith et al., (2004)

$$
\varphi_{e}=\varphi_{a v g}\left(1-V_{s h}\right)
$$

where $\varphi_{\text {avg }}$ is the average porosity and can be calculated as

$$
\varphi_{\text {avg }}=\sqrt{\frac{\varphi_{\text {density }}+\varphi_{N P H I}}{2}}
$$

where $\varphi_{\text {density }}$ is density porosity and $\varphi_{N P H I}$ is neutron porosity. The $\varphi_{N P H I}$ is determined directly from neutron log and generalized formula for $\varphi_{\text {density }}$ is represented as

$$
\varphi_{\text {density }}=\frac{\rho_{\text {matrix }}-\rho_{\text {log }}}{\rho_{\text {matrix }}-\rho_{\text {fluid }}}
$$

where $\rho_{\log }$ is the density of the respective formation obtained directly from density logs, $\rho_{\text {matrix }}$ is the matrix density equal to $2.65 \mathrm{~g} / \mathrm{cm}^{3}$ in the case of sands and $\rho_{\text {fuid }}$ is the fluid density normally assumed as to $1 \mathrm{~g} / \mathrm{cm}^{3}$.

For petrophysical analysis, differentiation between formation fluids is a key parameter (Tiab and Donaldson, 2004). The $S_{w}$ refers to pore volume occupied by water. Different models for calculating $S_{w}$ such as Archie's equation for clean sand, the Indonesian equation for 'dirty formation' as well as the Dual water are based on the lithology. Thin interbedded shales degrade the quality of C-Interval sand. Therefore, $S_{w}$ is estimated through the Indonesian equation.

$$
S_{w}=\left\{\frac{\sqrt{\frac{1}{R_{t}}}}{\left(\frac{V_{s h}^{\left(1-0.5 V_{s h}\right)}}{\sqrt{R_{s h}}}\right)+\sqrt{\frac{\varphi_{e}^{m}}{a R_{w}}}}\right\}
$$

where $S_{w}$ is water saturation, $R_{t}, R_{s h}$ and $R_{w}$ are the true, shale and water resistivity of the respective formation obtained from resistivity logs, $m$ and $a$ are the cementation and tortuosity factors normally taken equal to 2 and 1 for sandstones (Guéguen and Palciauskas, 1994).

\section{Seismic Stratigraphy of C-Interval Horizon}

Major horizons are identified using synthetic seismograms which also include the prolific sand interval horizons of the Lower Goru Formation. Three major sand interval horizons namely B-Interval, C-

Table 1. Details of data sets used in the current study

\begin{tabular}{ccccc}
\hline \hline \multicolumn{5}{c}{ Well Data } \\
\hline Well & Total Depth TD $(\mathrm{m})$ & TD Formation & TD Horizon & Geophysical Logs \\
\hline W-1 & 3587 & Lower Goru & C-Sand & GR, DT, RHOB, LN, NPHI, PEF \\
W-2 & 3489 & Lower Goru & B-Sand & GR, DT, RHOB, LN, NPHI, PEF \\
W-3 & 3380 & Lower Goru & C-Sand & GR, DT, RHOB, LN, NPHI, PEF \\
W-4 & 3370 & Lower Goru & C-Sand & GR, DT, RHOB, LN, NPHI, PEF \\
W-5 & 3400 & Lower Goru & B-Sand & GR, DT, RHOB, LN, NPHI, PEF \\
W-6 & 3430 & Lower Goru & C-Sand & GR, DT, RHOB, LN, NPHI, PEF \\
\hline \multicolumn{7}{c}{ Seismic Data } \\
\hline Type & Total Time & Sampling Interval & Inlines & Crosslines \\
\hline 3D & $4.5 \mathrm{sec}$ & $4 \mathrm{~ms}$ & 394 & 158 \\
\hline
\end{tabular}




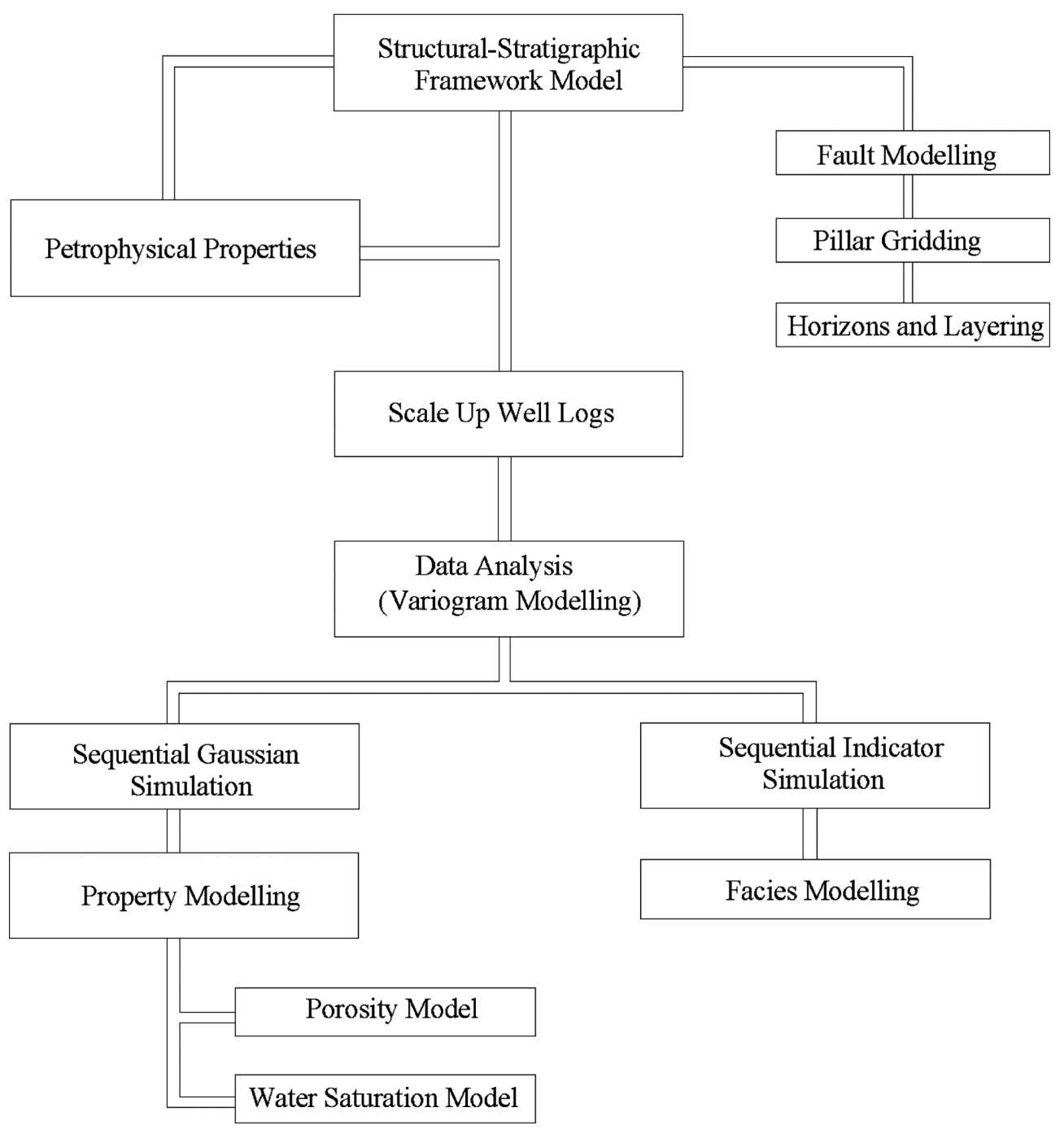

Figure 4. Flow chart diagram of the static modeling procedure in the current study.

Interval, and D-Interval are identified and interpreted in addition to top Lower Goru on the seismic section. The C-Interval horizon was interpreted on the whole seismic 3D cube using horizon mapping. The $2 \mathrm{D}$ seismic sections were extracted from the $3 \mathrm{D}$ seismic cube at key locations.

\section{Static Models}

Static modelling initiated with detailed seismic interpretation of Sawan field in order to delineate the stratigraphy of C-Interval. Two horizons, i.e., Top C-Interval and Top B-Interval were picked and interpreted on the whole $3 \mathrm{D}$ seismic cube as a pre-requisite for the reservoir model (Casentino, 2001; Barclay et al., 2008). The initial model is built by adding the interpreted horizons as layers. These layers are carefully designed as they determine the orientation and cell thicknesses of the resulting grids. These grid cells determine the property variation within the grid system and display the results spatially along these layers.

Building a sound structural model is the foundation for a static model. This model was built with standard procedures including, generation of a depth contour map, fault modeling, insertion of well tops (such as top and base of reservoir) and layering between top and base of the reservoir. Upscaling is a process of averaging attribute values and then assigning a value to each grid cell at the well locations. Each grid cell with assigned value then acts as a starting point for property modeling. Before spatially populating the reservoir properties, or entering into the $3 \mathrm{D}$ grid system, it is necessary to scale up the well $\log$ properties in order to bridge the gap between resolution of both datasets. There are different methods typically used for averaging (scaling up) such as the arithmetic mean, harmonic mean and geometric mean methods. Most commonly the, arithmetic mean method is used for scaling up the $\varphi$ and $S_{w}$ parameters (Baldawi and Buraq, 2015).

The Sequential Simulation Indicator (SIS) is a geostatistical simulation technique applied to a widespread range of data sets and relies on an indicator (variogram aided kriging). When working in a gridding system, SIS computes or estimates a value at a free grid cell by using both input and simulated data. Multiple realizations of a property are generated, which are then assessed for uncertainty with the most appropriate realization. SIS geostatistical simulation is widely used in reservoir modeling to predict variables such as facies (Zhou et al., 2018). The first stage of the process involves the 'Binary Indicator Transform' which transforms all original well data into indicator variables describing 


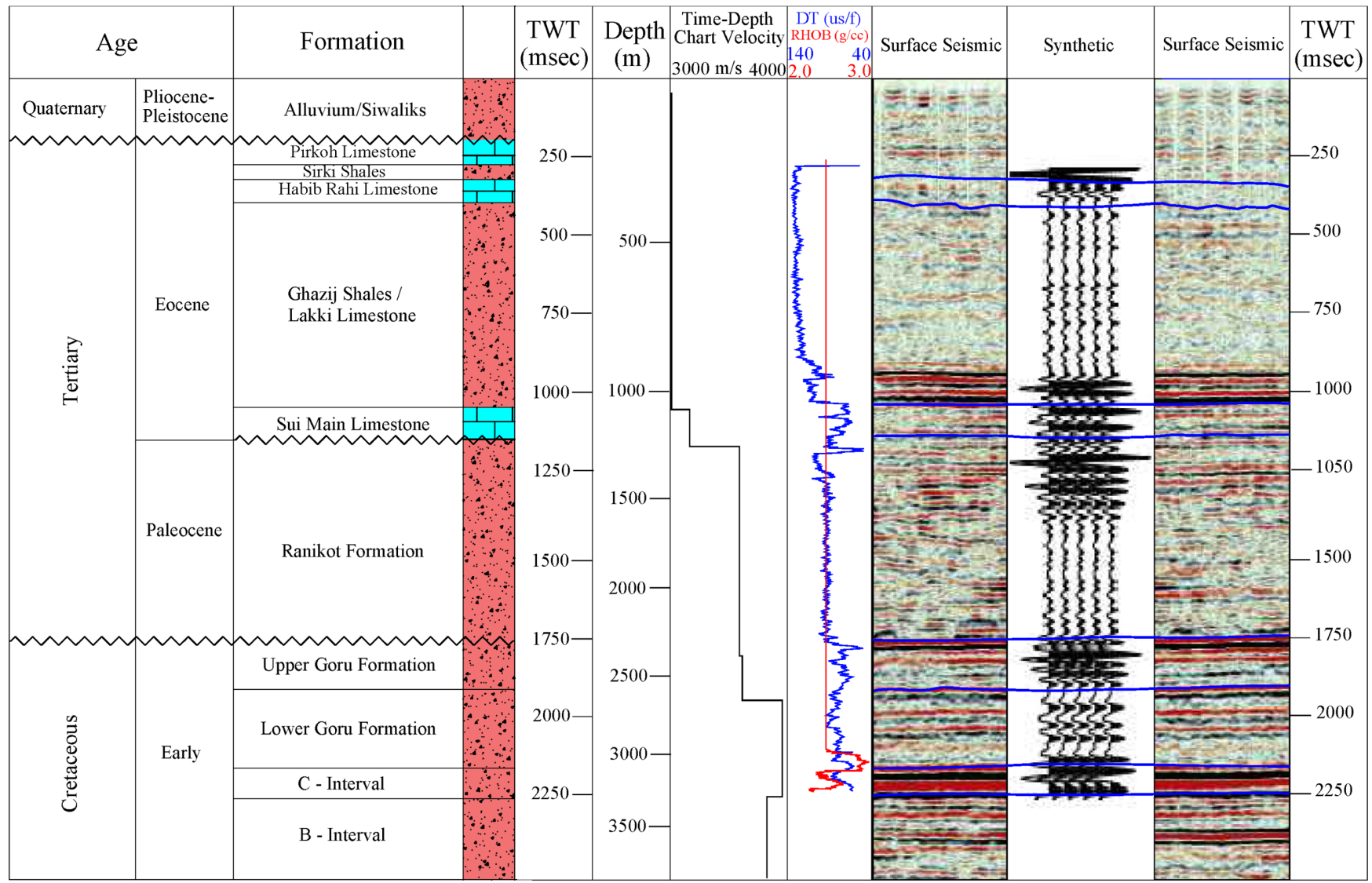

Lithology:

$\therefore$ Clastic Rocks Carbonate Rocks

Figure 5. Well-Seismic tie and T-D relationship for well W-5 identifying key seismic horizons and unconformities.

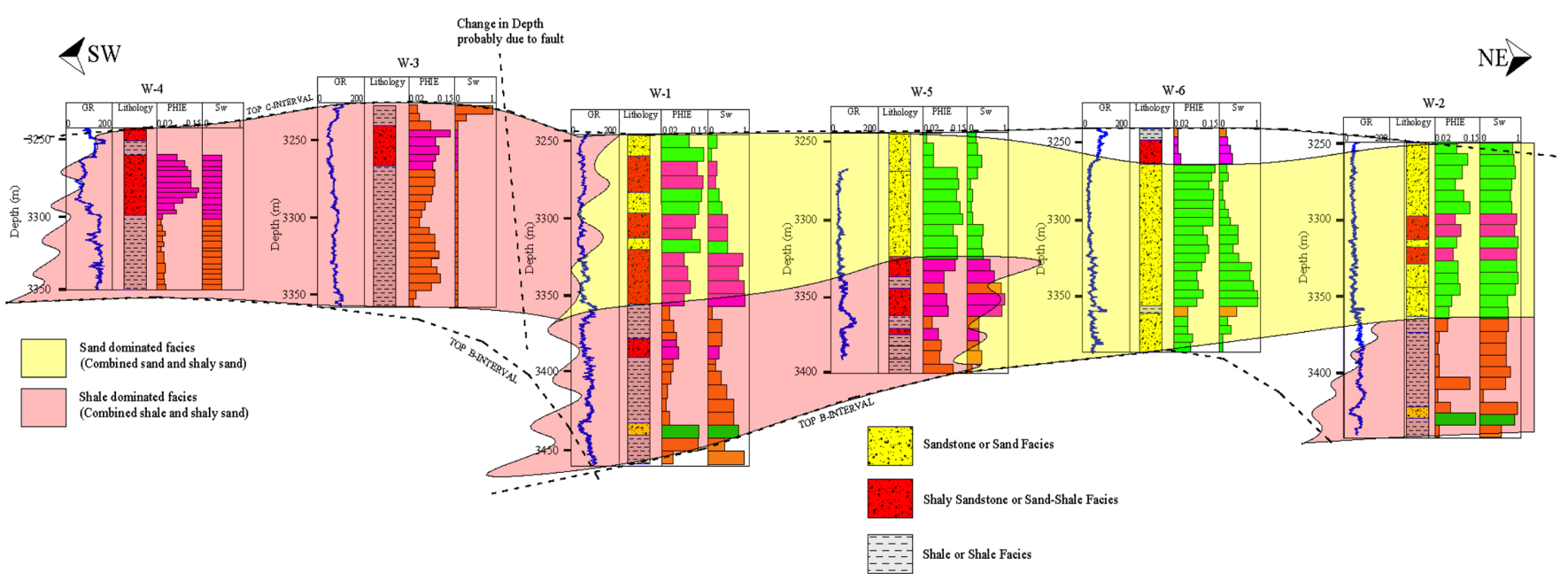

Figure 6. Well correlation between $W-4, W-3, W-1, W-5, W-6$ and $W-2$ for facies, $S_{w}$ and $\varphi_{e}$ in addition to basic depositional setting.

the probability values. This transformed data is assigned into a simulation grid and random search paths are generated through grid nodes. Kriging and variogram analysis are applied to estimate mean values for the indicator variables at each node. This analysis relies on the values of surrounding data points for each node, the distance of each node to the surrounding data points, variogram parameters, search parameters and property variations (facies variation in this case). The process is repeated until all the nodes in the grid obtains a value.

The procedure for initiating the Sequential Gaussian Simulation (SGS) process requires the univariate stochastic property values be assigned, then a score transformation to normal distribution is executed assuming the multinormality of the normal scores (Musawi and Jawad, 2019). The multinormal supposition confirms that the provisional spreading at a given site is with standard mean and vari- 
ance provided by kriging. Reproduction of normal score values at grid nodes is performed sequentially with kriging using the standard score variogram and zero mean (Isaaks, 1991; Goovaerts, 1997; Deutsch and Journel, 1998). Once all standard scores are simulated, they are back-transformed to their original values. Two reservoir properties, i.e., $\varphi_{e}$ and $S_{w}$ were modelled using this simulation method in a 3D domain.

\section{Variogram Modelling}

The variogram is calculated using the following equation (Cressie, 1993; Khan et al., 2016).

$$
\gamma(h)=0.5 E[Z(X+h)-Z(X)]^{2}
$$

where the semi-variance is denoted by $\gamma(h)$, expectation by $E$, location by $X$, sampling distance or distance of separation by $h$, and observed value by $Z$. The relationship amongst the experimental values and their scatter is measured by the expression in equation (5).

Since the variogram shows the variability between sample pairs with respect to $h$ the distance therefore leads to zero (i.e., $h>0$ ) and the variability should also be zero. If the variability value is greater than zero (i.e., $\gamma(h)>0$ ) then the remaining value is known as the nugget effect $\left(C_{0}\right)$. The Sill $(S)$ is defined as, $C+C_{0}$, where, $C$ is treated as $S$ provided $C_{0}$ is zero.

Numerous possible variogram model types can be applied to these data sets; the most basic and common types are the spherical, linear and exponential models (Gringarten et al., 1999; Shamo et al., 2012). For the majority of this data, any one of the basic models (spherical, linear and exponential) will produce an acceptable result. As such, the spherical model has been selected for this study.

The expression for the spherical type model is given below,

$$
\gamma(h)=C_{0}+\left(C-C_{0}\right)\left[\frac{1.5 h}{\alpha-0.5\left(\frac{h}{\alpha}\right)}\right]
$$

where $\alpha$ is the range, $C_{0}$ is the nugget effect and $C$ is the sill of the variogram.

Nearly all the gridding techniques require a weighted average approach to intelligently predict values at the grid nodes between the sample locations. In this study, a weighted linear average is used and is given below with the expression for $T$.

$$
T=w_{1} g_{1}+w_{2} g_{2}+w_{3} g_{3}+\cdots+w_{m} g_{m}
$$

where $T$ is the estimator, $w_{1}, w_{2}, w_{3}, \ldots, w_{m}$ are the weighting factors and $g_{1}, g_{2}, g_{3}, \ldots, g_{m}$ are the property values at the well locations. The weighting factors were estimated using the kriging technique. Kriging is based on interpolation by estimating the property at unknown location within a grid taking into consideration the spatial variability in the property. Therefore, it requires use of a variogram model to estimate the variability within the data set in order to determine the weight factors.

The kriging matrix is defined below as,

$$
\left(\begin{array}{cccc}
\gamma_{(1,1)} & \cdots & \gamma_{(1, X)} & \lambda \\
\cdot & \cdots & \cdot & \lambda \\
\cdot & \cdots & \cdot & \lambda \\
\cdot & \cdots & \cdot & \lambda \\
\gamma_{(N, 1)} & \cdots & \gamma_{(N, N)} & \lambda \\
1 & \cdots & 1 & 0
\end{array}\right)\left(\begin{array}{c}
w_{1} \\
\cdot \\
\cdot \\
\cdot \\
w_{N} \\
1
\end{array}\right)=\left(\begin{array}{c}
\gamma_{(1, X)} \\
\cdot \\
\cdot \\
\cdot \\
\gamma_{(N, X)} \\
1
\end{array}\right)
$$

In above expression, $\gamma$ stands for spherical variogram model, $\lambda$ for Lagrange multiplier so that the sum of weights is equal to one ( $\sum w_{m}=1$ ), $N$ is the number of data points, and $X$ is the location, where the property value is required.

Multiple realizations are made for the current work (facies distribution, $\varphi_{e}$ and $S_{w}$ distribution) where variograms were generated for use in interpolation using the kriging method. Variograms were constructed in major, minor and vertical directions as shown in Figs. $7 \mathrm{a}$ and $7 \mathrm{~b}$ for $\varphi_{e}$ and $S_{w}$ respectively and used in kriging method for interpolation through the 3D network. The variogram parameters used are shown in Table 2.

\section{Acoustic Impedance Inversion}

Seismic inversion plays a significant role for the petroleum sector to reduce the uncertainties inherent in exploration for oil and gas. Most of the exploration and production sector rely on seismic inversion methods to generate a detailed view of subsurface geology. Seismic inversion techniques convert reflectivity data that represents an interface property into a layer property of a rock (Barclay et al., 2008). Inversion is a method for prediction, calculation and inferencing physical parameters from real data (Sen, 2006). The model-based inversion is a robust way of estimating impedance from seismic. It uses a 'Generalized Linear Inversion' algorithm that modifies the initial geological model until the calculated trace model matches the observed seismic within some acceptable limits (Gavotti et al., 2013). In order to build an accurate initial model, the interpreter must have a good geological knowledge of the study area. The generalized linear inversion algorithm is based on an objective function that calculates misfit error between the predicted model and the observed seismic traces.

$$
j=w_{a}(C-W T)+w_{b}(G-H T)
$$

where $C$ represents seismic data, $W$ is the extracted wavelet, $G$ is initial guess model, $H$ is an integration operator and $w_{a}, w_{b}$ are weights. The statistical wavelet has been derived from seismic data within a defined window ranging from 1,900 to $2,400 \mathrm{~ms}$ with a wavelength measuring $200 \mathrm{~ms}$ and zero phase.

\section{Results and Discussion}

As a first step in the development of 3D static models, the top and bottom of the reservoir should be positively identified on the seismic data. In the next step, the reservoir parameters obtained from well data analysis will be used as a constraint for the static models prepared from 3D seismic data. Time-depth relationship has been developed by generating a synthetic seismogram as shown in Fig. 5. The well tops were displayed on the seismic section to identify individual horizons for interpretation. 
Distance of Separation $h$

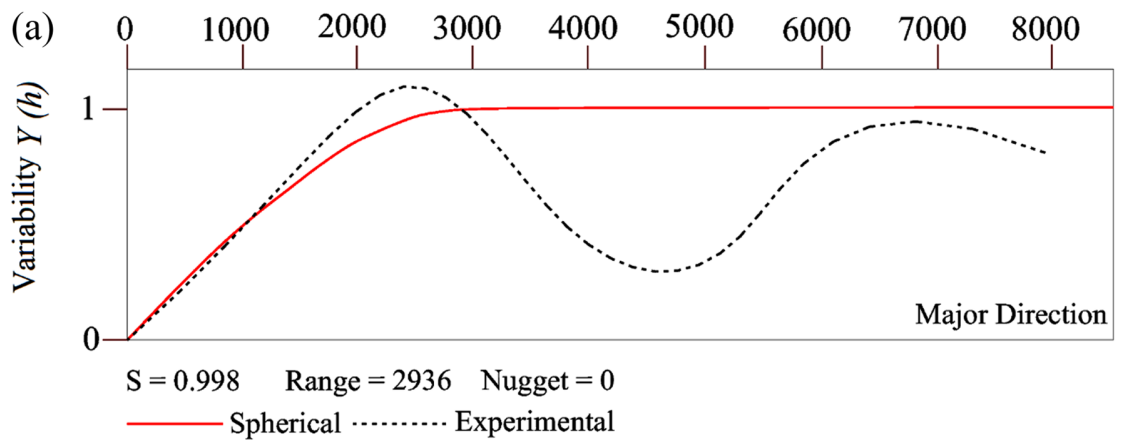

Distance of Separation $h$

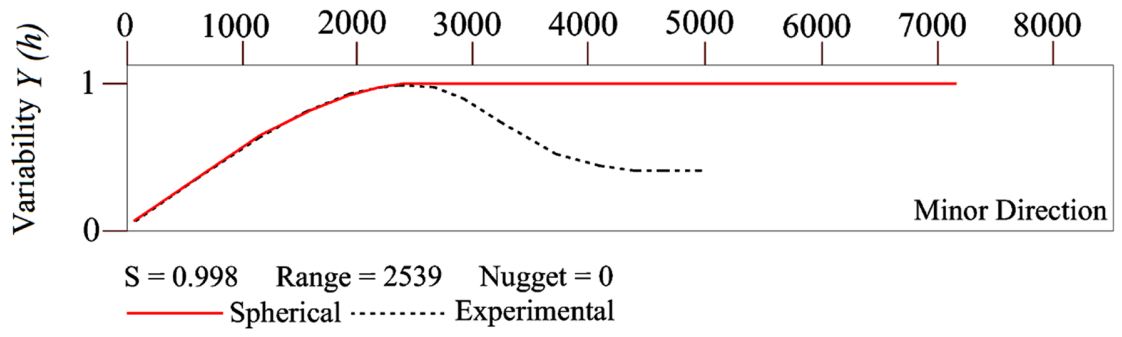

Distance of Separation $h$

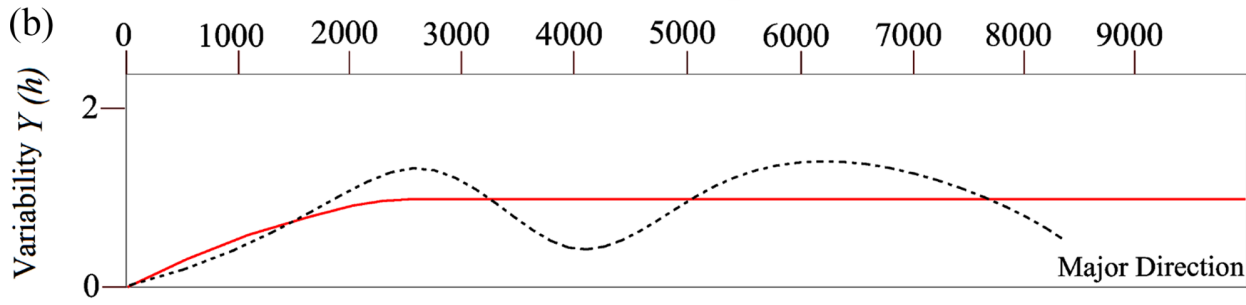

$\mathrm{S}=0.998$ Range $=2748.4$ Nugget $=0$

Spherical ........... Experimental

Distance of Separation $h$

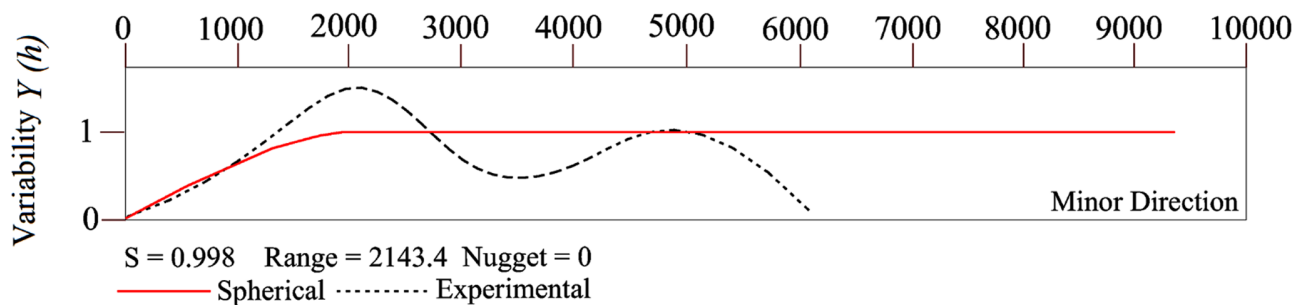

Figure 7. (a) Variogram models in both major and minor directions for $\varphi_{e}$; (b) Variogram models in both major and minor directions for $S_{w}$.

Table 2. Petrophysical properties of the C-Interval Sand utilizing the available well log data

\begin{tabular}{ccccc}
\hline \hline & \multicolumn{2}{c}{ Water Saturation } & & \\
\hline Direction & Type Variogram & Nugget & Sill & Range \\
\hline Major direction & Spherical & 0 & 0.998 & 2748 \\
Minor Direction & Spherical & 0 & 0.998 & 2143 \\
Vertical & Spherical & 0.043 & 0.951 & 63 \\
\hline Direction & Effective Porosity & & Sill & Range \\
\hline Major direction & Type Variogram & Nugget & 0.998 & 2936 \\
Minor Direction & Spherical & 0 & 0.998 & 2539 \\
Vertical & Spherical & 0 & 0.953 & 65 \\
\hline
\end{tabular}




\section{Well Logs Data Analysis}

Wireline log analysis is typically used to evaluate subsurface geological conditions and to estimate reservoir characteristics while in this study they also facilitate the identification and quantification of reservoir fluids (Ali et al., 2018). The estimation of petrophysical properties from wireline logs assist in the interpretation of a reservoir's lithology and improves the study of reservoir characterization (Fitch et al., 2015). A comprehensive petrophysical analysis for the Sawan field were performed to estimate key petrophysical properties such as $V_{s h}, \varphi, S_{w}$ etc. and to identify individual reservoir compartments. The averaged results of the well logs analysis are presented in Table 3. Potential gas zones can be identified by triple combo wire-

Table 3. Variogram parameters for the simulation

\begin{tabular}{ccccc}
\hline \hline Well Name & Depth $(\mathrm{m})$ & $V_{s h}(\%)$ & $\varphi_{e}(\%)$ & $S_{w}(\%)$ \\
\hline W-1 & $3252-3319$ & 17 & 13 & 47 \\
W-2 & $3280-3305$ & 24 & 10 & 55 \\
W-3 & $3240-3260$ & 21 & 9 & 60 \\
W-4 & $3260-3290$ & 20 & 10 & 50 \\
W-5 & $3267-3323$ & 9 & 12 & 45 \\
W-6 & $3263-3325$ & 9 & 13 & 47 \\
\hline
\end{tabular}

line logs response such as low-medium values of GR, high resistivity values, low $\rho$ and $\varphi_{N P H I}$ values. The petrophysical properties of the C-Interval sands are delineated from the available wireline logs in $\mathrm{W}-1$, W-2, W-3, W-4, W-5 and W-6 as shown in Fig. 6.

Table 3 shows the various calculated parameters from the suite of well-log data. The prolific C-Interval sand encountered at different wells within the study area show good effective reservoir properties. In well $\mathrm{W}-1$, the C-Interval sand is encountered with maximum thickness of $199 \mathrm{~m}$ (Fig. 6). Based on our petrophysical analysis a $67 \mathrm{~m}$ thick net pay zone of clean sand can be delineated, with depth ranging between 3,252 and 3,319 m. This sandy zone exhibits a smaller percentage of $V_{s h}(17 \%), \varphi_{e}(13 \%)$, and an economic percentage of pores filled with hydrocarbons (53\%). This highly porous (total porosity 18\%) thick pay zone has a substantial hydrocarbon saturation and qualifies as an excellent reservoir (Rider, 2002). Well log analysis results of other wells such as W-2, W-3, W-4, W-5 and W-6 also shows a presence of significant sand bodies having $\varphi_{e}$ ranges from 9 to $13 \%$ and $S_{w}$ at reservoir interval are 45 to $60 \%$.

In addition, the well correlation presented in Fig. 6 provides insight on the depositional trends of the C-Interval. The base of the C-Interval is dominated by shales and shaly sands whereas its upper section appears to be sand prone as seen in Fig 6. Indications are that the CInterval is deposited in a regressive environment where the litholo-


Figure 8. Core and lithologies description for well W-7. 
gies moves seaward (both sand and shale). It is also observed that the lithologies shale out towards the west and southwest, thus confirming the east to west depositional direction. The sand horizons are attributed to the shale content increasing towards southwest with decreasing $\varphi_{e}$. The decrease in shale content with an increase in $\varphi_{e}$ is observed in the northeast direction. The available core description from well W-7 suggest different lithologic properties as shown in Fig. 8. The top of C-Interval (between depths 3,405 and 3,470 m) is characterized by very coarse to medium grained, poorly to moderately sorted clean sandstone (referred as Sand facies in Fig. 6). Below the clean sandstone (between depths 3,470 and 3,538 m), very fine to medium grained moderately hard to very hard, highly carbonaceous sandstone is interlayered with moderately hard, platy, sub fissile, carbonaceous and micaceous shale and moderately hard to hard, slightly calcareous and carbonaceous siltstone (collectively these lithologies termed as shaly sand facies). Below depth 3,538 m, siltstone is interlayered with soft to firm, glauconitic shales (these lithologies are termed as shale facies; Fig. 8).

\section{Seismic Characteristics of C-Interval}

The key seismic horizons including C-Interval are identified through synthetic seismic correlation. The top of the C-Interval is recognized by a bright reflection due to the occurrence of sandstone in the upper part, where it generates a significant impedance contrast with the shales of the Upper Goru Formation. As a whole, the Lower Goru Formation was deposited in a deltaic setting over a ramp resulting in the deposition of interlayered sandstone and shales (Ahmed et al., 2004; Munir et al., 2011). An example of diagonal seismic cross section from 3D seismic is presented in Fig. 9. The early C-Interval deposition was dominated by regressions resulting in the deposition of offshore bars (Ahmed et al., 2004) (here referred as 'regressive sand bodies'). These sand bodies are positively identified on the seismic section by the thickening (broadening of seismic reflection patterns) within the C-Sand Interval as seen in Fig. 9. The regression possibly generated incision in the underlying sediments, which were later transported and deposited as regressive sand bodies. The regressive sand bodies have preferably flattened and bright bases due to the impedance contrast with the underlying sediments.

In order to obtain the depositional style and prolific sands in the CInterval, seismic sweetness attribute has been applied. The results are presented in Fig. 10 in correlation with the diagonal seismic section extracted from 3D seismic cube. The sweetness slice highlights some significant features (yellow-red color) within the C-Interval. One of the most significant features on the map is the coastline identified by the green-purple border (Fig. 10). This represent the coastal onlaps for the prograding sand wedge of the C-Interval. The further drop in sea level is believed to generate incision in the older sediments. The incision reworked the sediments and transported them basinward in the form of "sand bodies" which are regressive by nature and deposited under forced regression (Fig. 10). The isolated bright colored attribute near the interpreted coastline represents the presence of sand and are interpreted as channel bars as seen in Fig. 10. This suggests the presence of feeder channels for the regressive sand bodies as highlighted in Fig. 10. The C-Interval horizon also show variable thickness on the seismic section (Fig. 11). The thickness of the horizon decreases towards the northeast due to the presence of coastline and increases southwest towards the shelf margin forming a regressive body. The increase in thickness is indicated by the broad amplitudes on the seismic section as seen in Fig. 11.

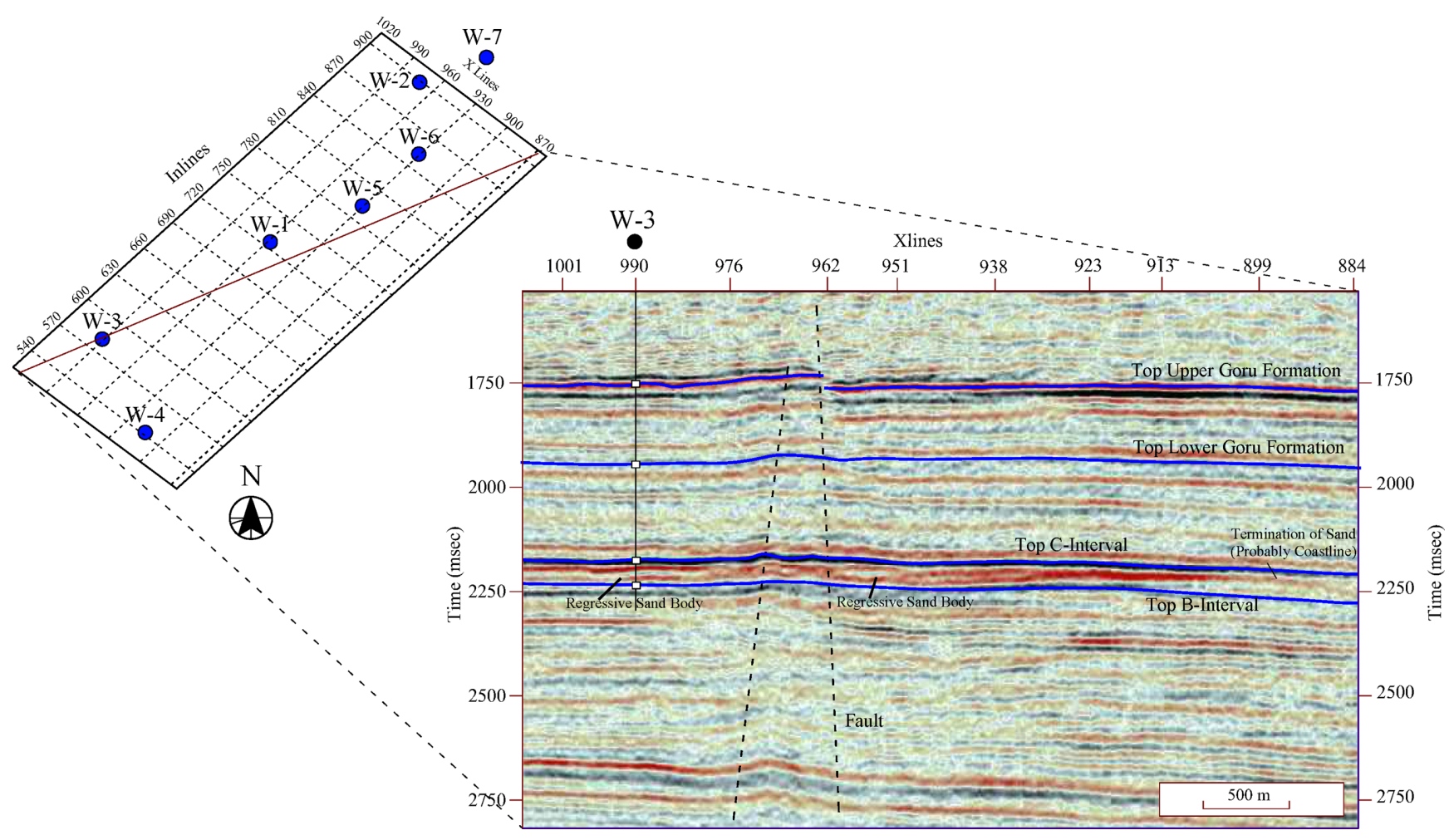

Figure 9. Example of an interpreted section with key seismic horizons obtained as a diagonal slice from 3D seismic cube. 


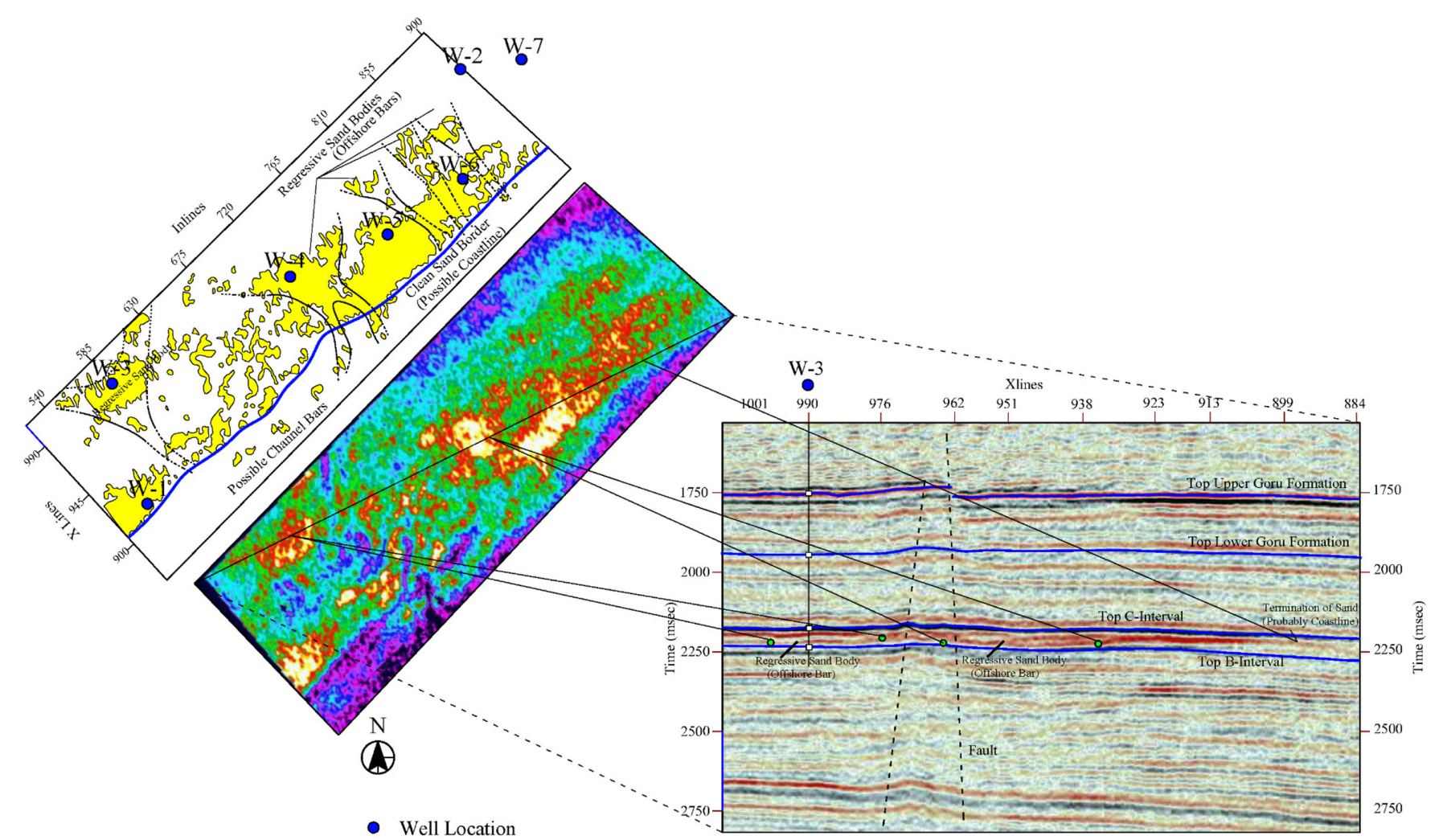

Figure 10. Interpreted seismic sweetness attribute for the C-Interval of Lower Goru Formation. The figure highlights the location of sand bodies and possible coastline in addition to key seismic horizons.

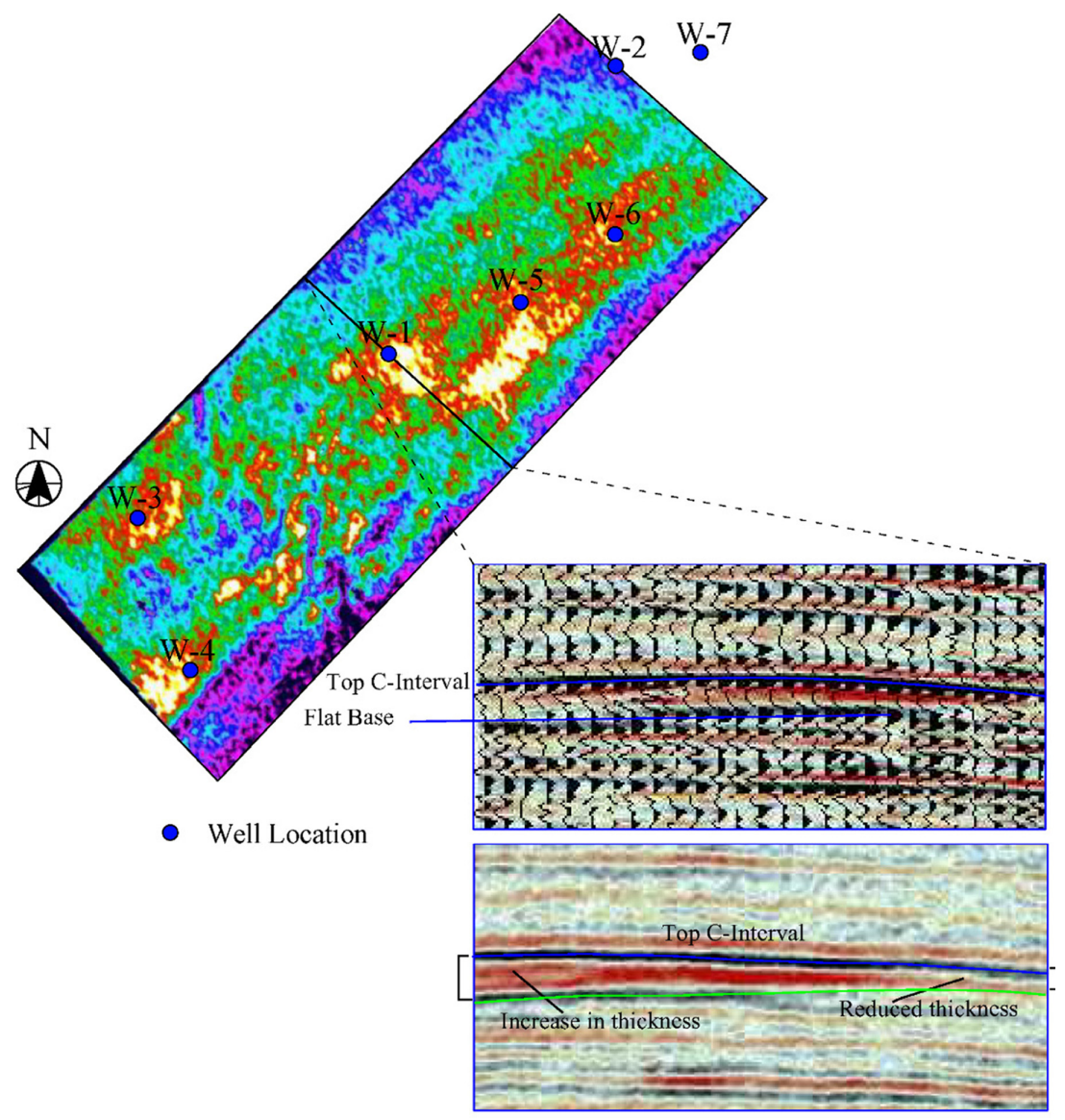

\section{D Facies Model}

In order to build 3D facies and property models, the layering of the initial grid is required to make a grid skeleton. These layers are inserted in the initial grid at regular depth intervals as shown in Fig. 12. The GR $\log$ is calibrated with known lithologies to define specific lithofacies at well locations. Three facies are defined namely sand, shaly sand and shale (as discussed in Section 4.1). These facies logs were scaled up and distributed through SIS. Figure 13 shows a $3 \mathrm{D}$ view of the resultant facies model. Modeling results indicate that $V_{s h}$ increases towards the southwest direction which is consistent with the more basinward setting of the reservoir (Ahmed et al., 2004; Munir et al., 2011). The dominant sand facies are distributed in the northeast direction along the interpreted coastline and marginal setting. The northeastern portion is characterized as a prolific sand facies as depicted in Figs. 6, 9,10 and 13 .

\section{D Effective porosity $\left(\varphi_{e}\right)$ Model}

A three-dimensional view of $\varphi_{e}$ model of Sawan field is shown in Fig. 14. The SGS method was used to estimate reservoir porosity beyond wells locations. The map shows good 


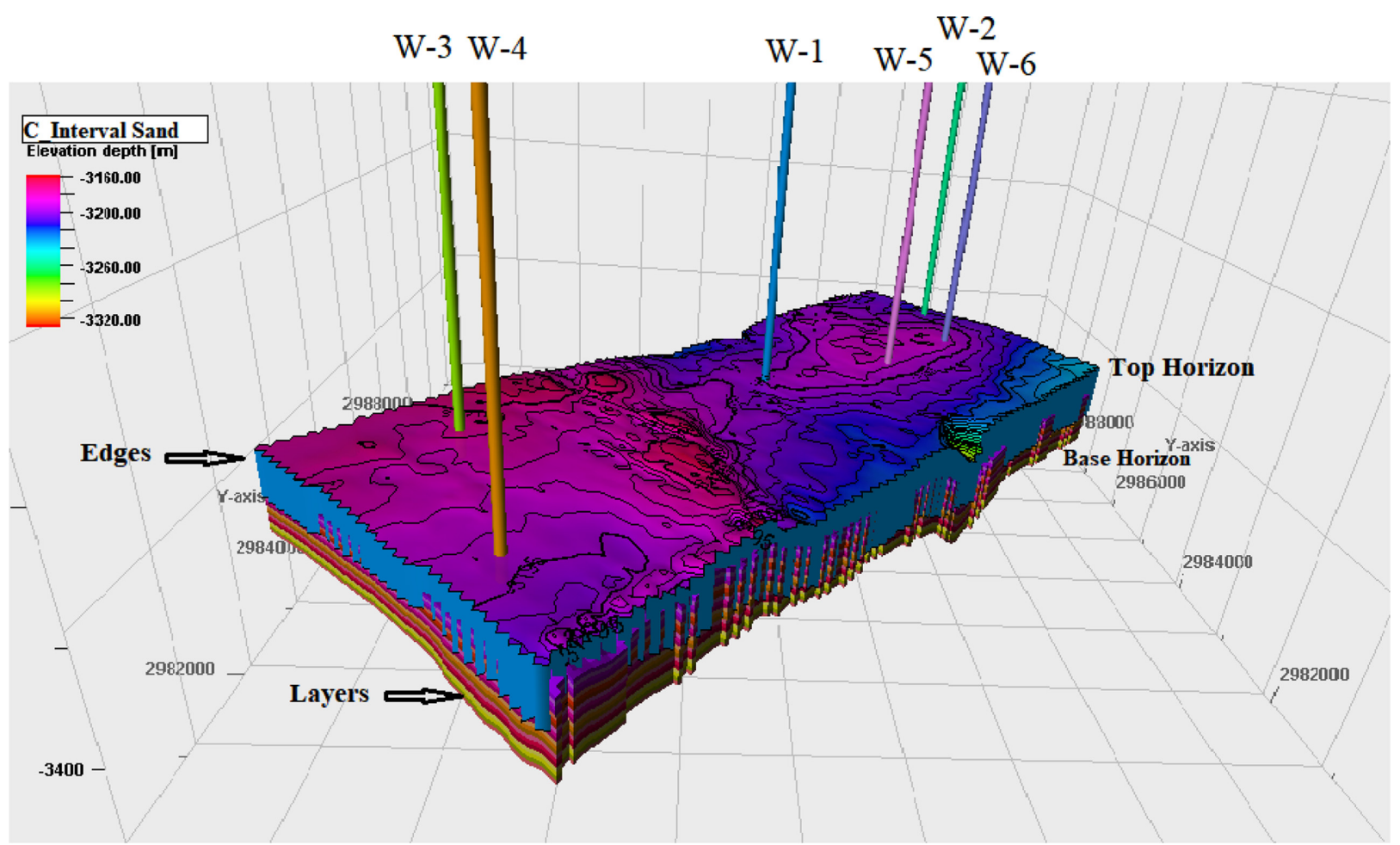

Figure 12. Defined structural layers for reservoir static model.

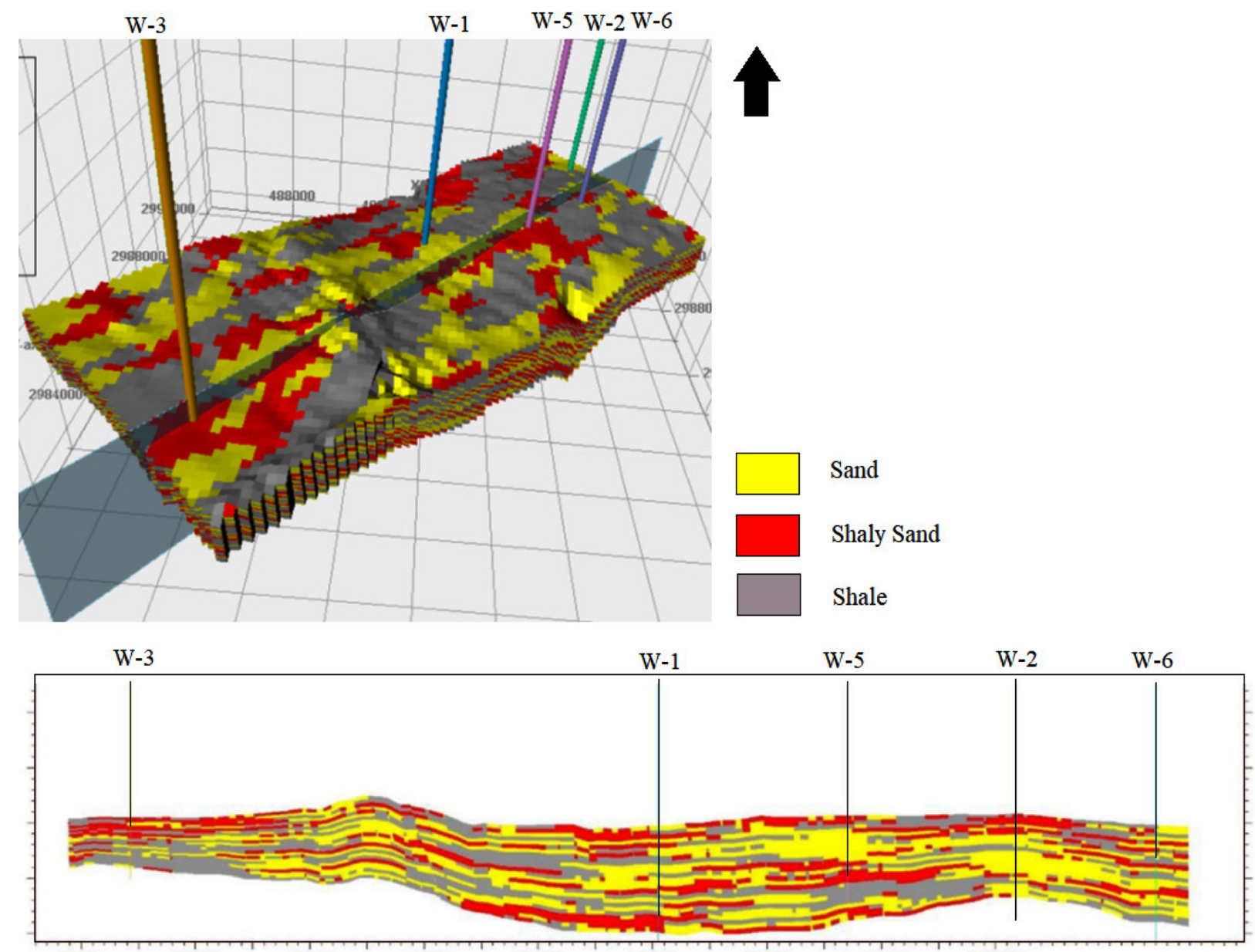

Figure 13. Resulting facies model after sequential indicator simulation. 


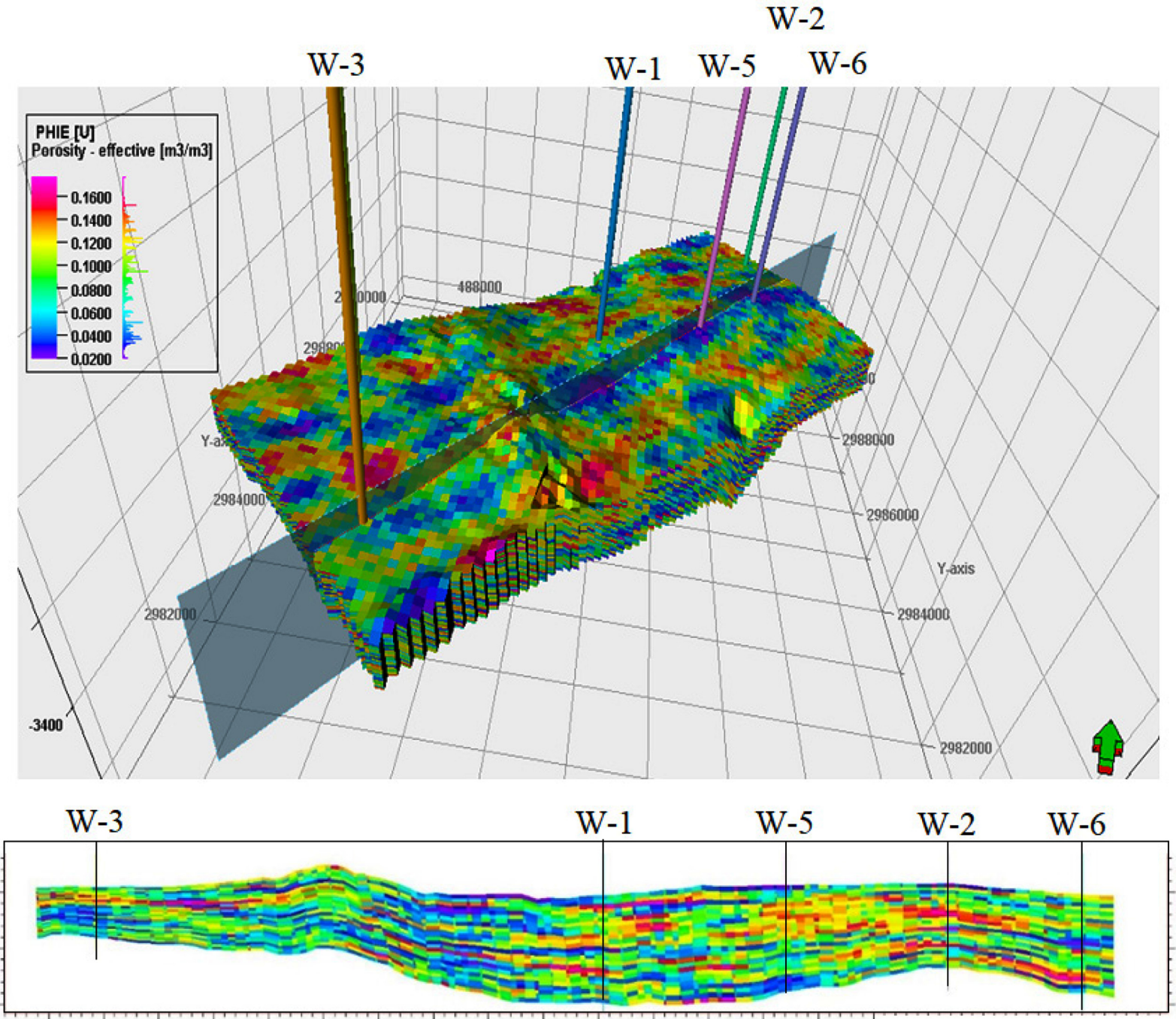

Figure 14. Resulting $\varphi_{e}$ model after sequential Gaussian simulation.

$\varphi_{e}$ values at some region which ranges from 8 to $16 \%$ and indicate that the wells are located within good $\varphi_{e}$ zones. For a detailed visualization of the $\varphi_{e}$ distribution in subsurface, a cross section has been drawn as shown in Fig. 14 oriented from northeast to southwest direction. The $3 \mathrm{D}$ view depicts that C-Interval is characterized by higher $\varphi_{e}$ range (16\%) towards the northeastern side, indicating that the reservoir holds economical quantities of hydrocarbons. This zone is correlated with clean shelfal and coastal sand deposits. However, the $\varphi_{e}$ decreases towards southwest with range 0 to $5 \%$ which suggests that the chances of economical production to be pessimistic, as this zone is correlated with shelf and basinal settings where shale has accumulated.

\section{D Water Saturation $\left(S_{w}\right)$ Model}

A three-dimensional $S_{w}$ model gives a direct indication about the percentage of hydrocarbons contained by the formation. For a prolific zone of interest, interpreter search out those locations where low $S_{w}$ and high $\varphi_{e}$ are present. Figure 15 shows a computed spatial distribution of $S_{w}$ in the study area with low $S_{w}$ around well locations. A cross section of $S_{w}$ from northeast to southwest direction clearly reveals a subsurface distribution of $S_{w}$ ranging from 40 to $50 \%$ in the study area.

\section{Model Based Inversion}

Seismic impedance inversion is applied to the 3D seismic cube with an example of extracted impedance section provided in Fig. 16. In general, shale horizons exhibit low seismic impedance with sand horizons having high seismic impedance with the exception of the CInterval. The low impedance of C-Interval is attributed to the accumulation of clean sands with the presence of hydrocarbons (gas). Furthermore, probable gas sand facies were identified within the C-Interval (identified by green color patches within the C-Interval, Fig. 16). The model based inversion resolved anomalous zones with low impedance values ranging from 7,000 to $9,000(\mathrm{~m} / \mathrm{s})(\mathrm{g} / \mathrm{cc})$ in the southern compartment as shown in Fig. 16. It is important to mention that seismic impedance inversion is used here in order to improve the confidence level of our results from static modelling (SIS and SGS) to confirm the presence of gas sand facies for prospect generation. Similarly, the results extracted through sweetness seismic attribute have highlighted the presence of possible anomalous sand bodies, where our static modelling (SIS and SGS) results have shown good $\varphi_{e}$ and low $S_{w}$ values. The seismic post stack impedance inversion can be utilized to extract spatial distribution of reservoir properties e.g., $\varphi$ via 


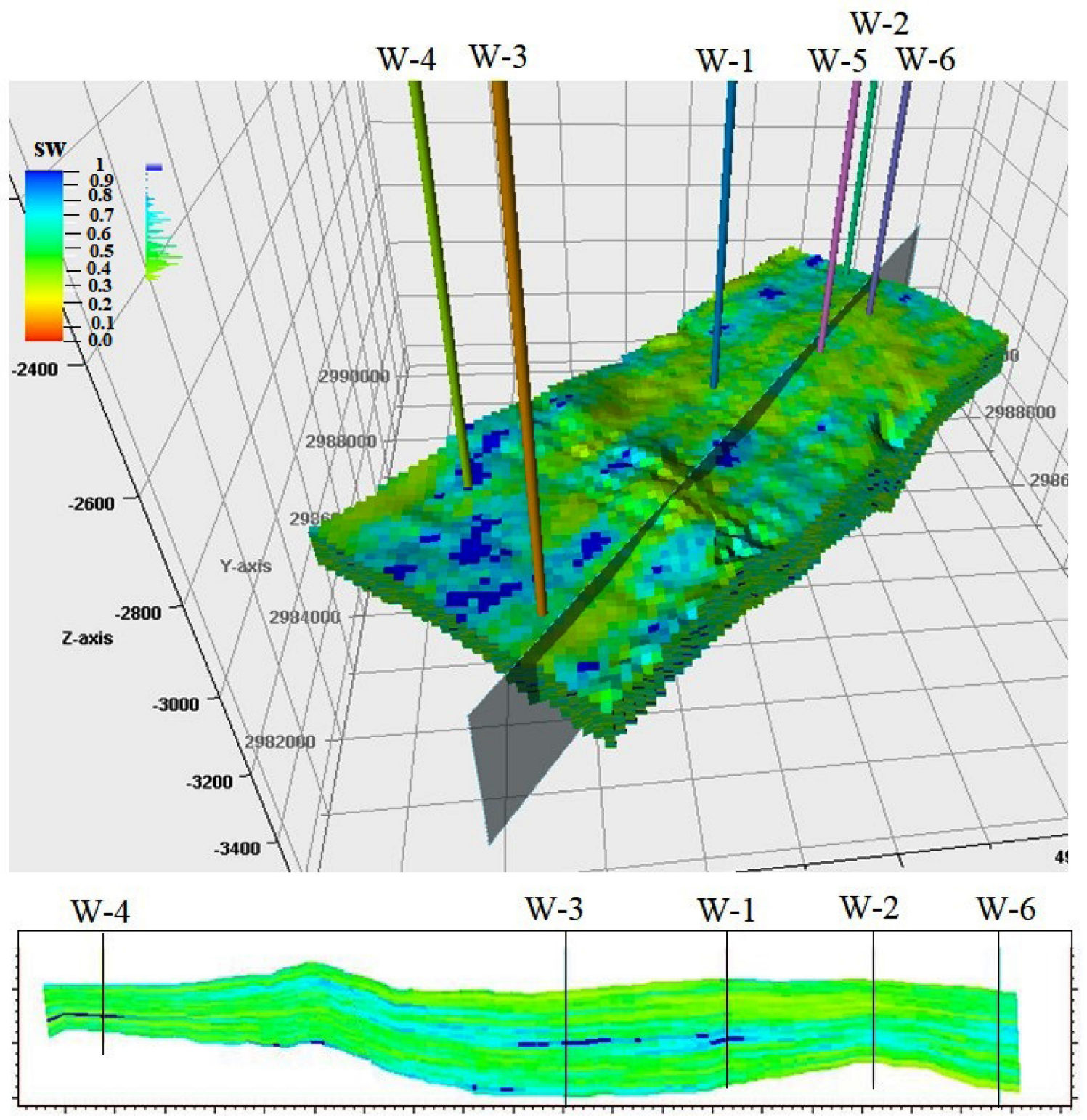

Figure 15. Resulting $S_{w}$ model after sequential Gaussian simulation.

geostatistical relationships (Ali et al., 2018), but the focus of this study is on static modelling to obtain the spatial distribution of different complex reservoir properties i.e., $\varphi$ and $S_{w}$. Furthermore, except porosity the spatial distribution of reservoir properties like $S_{w}$ via seismic post stack impedance inversion can be highly questionable (Ali et al., 2019), however, that is not the case for static modelling.

\section{Overall Significance of the Study}

This study helps to improve the understanding of heterogeneities in spatial distribution of important reservoir properties ultimately leading towards better 3D subsurface reservoir characterization. The techniques presented in this study have been applied to various oilfields in western Africa (Niger delta), Egypt, Iran and China to overcome the reservoir complexities and for the optimization and development of producing fields.

According to Adeoti et al. (2014) and Adelu et al. (2019), the appli- cation of SIS and SGS techniques provided realistic results in the Niger delta basin - one of the most productive hydrocarbon belts of the world with the Agbada formation having commercial accumulations of hydrocarbons. The presence of intercalations of sand shale and structurally deformed subsurface strata induced extreme heterogeneities in the Agbada formation. In order to realistically image these heterogeneities, 3D static modelling has been applied for estimation of discrete and continuous complex reservoir properties. Similarly, the application of static modelling successfully captured the reservoir (sandstone with thin streaks of shale) complexities in the South Umbarka area, Western Desert, Egypt and enhanced the recovery rate of the field (Abdel-Fattah et al., 2018).

Furthermore, a study in Hendijan oilfield in southern Iran showed a high confidence level for the results of SGS and SIS studies on subsurface development in complex reservoir scenario (Amanipoor, 2019). With the help of these techniques, the Ghar and Sarvak formations have been identified as promising reservoirs in the field. Furthermore, 


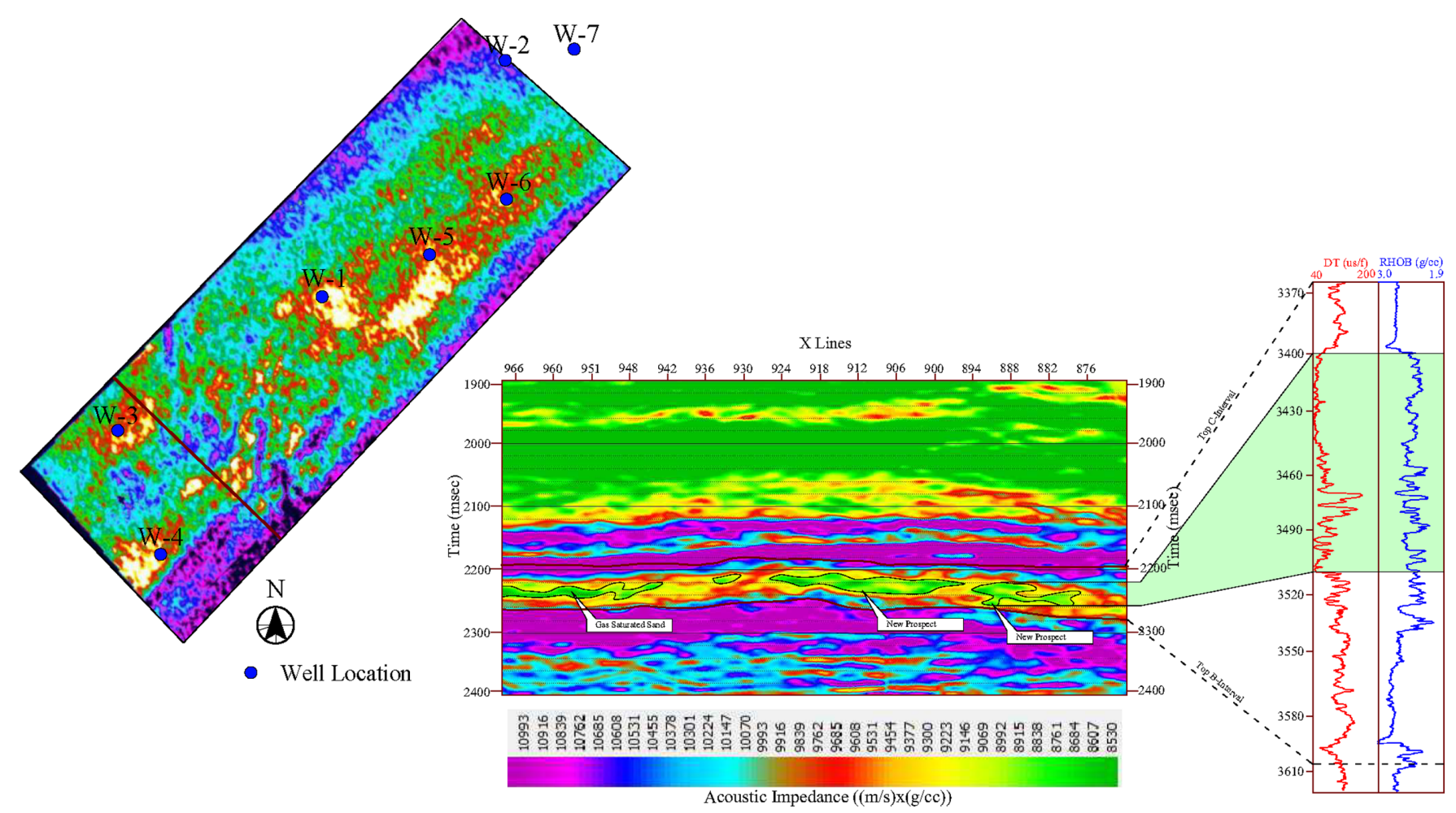

Figure 16. Seismic impedance inversion model and well logs example.

mapping of reservoir heterogeneities using the above-mentioned techniques for the Shenvsi oilfield (Dagan oilfield) in the south of Cangzhou City China (Al Rassas et al., 2020) showed promising results. Property modelling via SGS techniques for $\varphi_{e}, S_{w}, \delta$ and net to gross ratio confirmed, that the Es1 formation in block Nv32 is a prolific hydrocarbon reservoir. In addition, the use of sequence stratigraphic principles (in siliciclastic sediments) combined with static modelling have highlighted the potential linkage between reservoir properties and their depositional settings within the context of hydrocarbon exploitation. Overall, the techniques applied in this study appear to be useful for the analysis complex oil and gas basins with similar geological settings.

\section{Conclusions}

The study highlighted the reservoir potential of C-Interval within the Sawan area utilizing static modelling procedures in a 3D domain. Well logs and 3D seismic data coupled with SIS and SGS predicted the facies models and their reservoir potential in areas away from well locations. The seismic sweetness attribute successfully highlighted the paleo-coast line along which thick clean sand deposits. These sand deposits are ideally part of the prograding sands of the C-Interval horizon. The sweetness attribute also highlighted the regressive sand bodies forced basinward having apparent feeder channels indicated by isolated sand bars beyond the interpreted coastline. Modeling results indicate that the northeastern half of the investigated area appears to be sand prone with higher $\varphi_{e}$ and lower $S_{w}$ whereas, the southwestern half is dominated by shaly sands and shales with lower $\varphi_{e}$ and higher $S_{w}$. The forced regressive sand bodies resulting from transgressive- regressive cycles are interpreted as key locations for the accumulation of hydrocarbons. Seismic impedance inversion highlighted the CInterval as a low impedance horizon due to the clean sands saturated with hydrocarbons. As such, low impedance locations within the CInterval provide prospects for future hydrocarbon exploration and development.

\section{Acknowledgements}

The authors would like to thank Directorate General of Petroleum Concessions (DGPC), Pakistan, for allowing the use of seismic and well $\log$ data for research and publication purposes and Department of Earth Sciences, Quaid-i-Azam University, Islamabad, Pakistan, for providing the basic requirements to complete this work. The authors would like to thank (Mr. James Small - https://www.researchgate.net/ profile/James-Small-3) for reviewing and correcting this manuscript for English language as a native English Speaker within this field.

\section{References}

A1 Rassas, A., Ren, S., Sun, R., Zafar, A., Moharam, S., Guan, Z., Ahmed, A., and Alomaisi, M., 2020, Application of 3D reservoir geological model on Es1 formation, block Nv32, Shenvsi oilfield, China. Open Journal of Yangtze Oil and Gas, v. 5, pp. 54-72.

Amanipoor, H., 2019, Static modeling of the reservoir for estimate oil in place using the geostatistical method. Geodesy and Cartography, v. 45, pp. 147-153.

Abdel-Fattah, M.I., Metwalli, F.I., and El Sayed, I.M., 2018, oilfields development in South Umbarka area, Western Desert, Egypt. Journal 
of African Earth Sciences, v. 138, pp. 1-13.

Abeed, A.T., Lazim, S.A., and Hamied, R.S., 2019, Modeling of petrophysical properties and reserve estimation of Mishrif Formation-Garraf oil field. In IOP Conference Series: Materials Science and Engineering, v. 579, pp. 012037.

Adelu, A.O., Sanuade, O.A., Oboh, E.G., Offeh, E.O., Adewale, T., Mumuni, S., Oladapo, I.M., and Omolaiye, E.G., 2016, Hydrocarbon field evaluation: case study of 'Tadelu' field shallow offshore western Niger Delta, Nigeria. Arabian Journal of Geosciences, v. 9, pp. 1-30, doi:10.1007/s12517-015-2028-8

Adelu, A.O., Aderemi, A.A., Akanji, A.O., Sanuade, O.A., Kaka, S.I., Afolabi, O., Olugbeminga, S., and Oke, R., 2019, Application of 3D static modeling for optimal reservoir characterization. Journal of African Earth Sciences, v. 152, pp. 184-196.

Adeoti, L., Onyekachi, N., Olatinsu, O., Fatoba, J., and Bello, M., 2014, Static reservoir modeling using well log and 3-D seismic data in a KN field, offshore Niger Delta, Nigeria. International Journal of Geosciences, v. 5, pp. 93-106.

Ahmed, N., Fink, P., Sturrock, S., Mahmood, T., and Ibrahim, M., 2004, Sequence stratigraphy as predictive tool in Lower Goru Fairway, lower and middle Indus platform, Pakistan. PAPG Annual Technical Conference Proceedings, Pakistan, pp. 85-105.

Ahmed, W., Azeem, A., Abid, M.F., Rasheed, A., and Aziz, K., 2013, Mesozoic structural architecture of the middle Indus Basin, Pakistan controls and implications, PAPG Annual Technical Conference Proceedings, Pakistan, pp. 1-13.

Aizebeokhai, A.P., and Olayinka, I., 2011, Structural and stratigraphic mapping of Emi field, offshore Niger Delta. Journal of Geology and Mining Research, v. 3, no. 2, pp. 25-38.

Ali, M.Y., and Farid, A., 2016, Cretaceous-Neogene structural evolution of SE Abu Dhabi, United Arab Emirates. Journal of Petroleum Geology, v. 39, pp. 221-225.

Ali, A., Alves, T.M., Saad, F.A., Ullah, M., and Toqeer, M., 2018, Resource potential of gas reservoirs in south Pakistan and adjacent Indian subcontinent revealed by post-stack inversion techniques. Journal of Natural Gas Science and Engineering, v. 49, pp. 41-55.

Ali, A., Younas, M., Ullah, M., Hussain, M., Toqeer, M., Bhatti, A.S., and Khan, A., 2019, Characterization of secondary reservoir potential via seismic inversion and attribute analysis: A case study. Journal of Petroleum Science and Engineering, v. 178, pp. 272-293.

Anwer, H.M., Alves, T.M., Ali, A., Zubair., 2017, Effects of sand-shale anisotropy on amplitude variation with angle (AVA) modelling: the Sawan Gas Field (Pakistan) as a key case-study for South Asia's sedimentary Basins. Journal of Asian Earth Sciences, v. 147, pp. 516-531.

Asquith, G.B., Krygowski, D., and Gibson, C.R., 2004, Basic well log analysis. American Association of Petroleum Geologists, v. 16, pp. 67.

Azeem, T., Chun, W., Khalid, P., and Qing, L., 2017, An integrated petrophysical and rock physics analysis to improve reservoir characterization of Cretaceous sand intervals in Middle Indus Basin. Pakistan. Journal of Geophysics and Engineering, v. 14, pp. 212.

Azeem, T., Chun, W.Y., Khalid, P., Ehsan, M.I., Rehman, F., and Naseem, A.A., 2018, Sweetness analysis of Lower Goru sandstone intervals of the Cretaceous age, Sawan gas field, Pakistan. Episodes, v. 41, pp. 235-247.

Azeem, T., Yanchun, W., Khalid, P., Xueqing, L., Yuan, F., and Lifang, C., 2016, An application of seismic attributes analysis for mapping of gas bearing sand zones in Sawan gas field, Pakistan. Acta Geodaetica et Geophysica, v. 51, pp. 723-744.

Baldawi, B., and Buraq, A., 2015, Building a 3D geological model using petrel software for Asmari reservoir, south eastern Iraq, Iraqi Journal of Science, v. 56, pp. 1750-1762.

Baouche, R., Sen, S., Debiane, K., and Ganguli, S.S., 2020, Integrated reservoir characterization of the Paleozoic and Mesozoic sandstones of the El Ouar field, Algeria. Journal of Petroleum Science and Engineering, v. 194, pp. 107551.
Barclay, F., and Brunn, A., Alfaro, J.C., Cooke, A., and Cooke, D., 2008, Seismic Inversion: Reading between the lines. Oilfield Review, v. 20, pp. 42-63.

Berger, A., Gier, S., and Krois, P., 2009, Porosity-preserving chlorite cements in shallow-marine volcaniclastic sandstones: Evidence from Cretaceous sandstones of the Sawan gas field, Pakistan. AAPG Bulletin, v. 93, pp. 595-615.

Benetatos, C., Viberti, D., Benetatos, C., and Viberti, D., 2010, Fully integrated hydrocarbon reservoir studies: myth or reality? American Journal of Applied Sciences, v. 7, pp. 1477-1486.

Casentino, L., 2001, Integrated reservoir studies. Editions TECNIP, Institut Francais Du Petrole Publication, France, 336 p.

Chongwain, G.M., Osinowo, O.O., Ntamak-Nida, M.J., and Nkwanyang, T.L., 2019, Lithological typing, depositional environment, and reservoir quality characterization of the "M-Field", offshore Douala Basin, Cameroon. Journal of Petroleum Exploration and Production Technology, v 9, pp. 1705-1721.

Cressie, N., 1993, Statistics for spatial data. John Wiley and Sons, New York, $928 \mathrm{p}$.

Cubizolle, F., Valding, T., Lacaze, S., and Pauget, F., 2015, Global method for seismic-well tie based on real time synthetic model. In SEG Technical Program Expanded Abstracts, pp. 1776-1781. doi:10.1190/segam20155862834.1

Doyen, P., 2007. Seismic Reservoir Characterization: an Earth Modelling Perspective. EAGE publications, Houston, v.2, pp. 255.

Deutsh, C.V., and Journel, A.G., 1997, Geostatistical Software Library and User's Guide, $2^{\text {nd }}$ Edition. Oxford University Press, New York, pp. 369.

Egermann, P., E., Lenormand, R., Longeron, D.G., and Zarcon, C., 2002, A Fast and Direct Method of Permeability Measurements on Drill Cuttings. SPE Reservoir Evaluation and Engineering, v. 8, pp. 269-275.

Fitch, P.J., Lovell, M.A., Davies, S.J., Pritchard, T., and Harvey, P.K., 2015, An integrated and quantitative approach to petrophysical heterogeneity. Marine and Petroleum Geology, v. 63, pp. 82-96.

Gavotti, P., Lawton, D., Margrave, G., and Issac, H., 2013, Poststack inversion of broadband seismic data from Alberta, Canada, Society of Exploration Geophysicists Annual Meeting, Houston, Texas, Paper Number, SEG-2013-1362, doi:10.1190/segam2013-1362.1

Godwill, P.A., and Waburko, J., 2016, Application of 3D reservoir modeling on Zao 21 oil block of Zilaitun Oil Field. Petroleum and Environmental Biotechnology, v. 7, pp. 262, doi:10.4172/2157-7463.1000262

Gringarten. E., and Deutsch, C.V., 2001, Teacher's Aide: Variogram Interpretation and Modelling. Mathematical Geology, v. 33, pp. 507-534.

Guéguen, Y., and Palciauskas, V., 1994, Introduction to the Physics of Rocks. Princeton University Press, 194 p.

Haldorsen, H.H., and Damsleth, E., 1990, Stochastic modelling. Journal of Petroleum Technology, v. 42, pp. 404-412.

Isaaks, E.H., and Srivastava, R.M., 1989, An introduction to applied geostatistics. Oxford University Press, New York, 561 p.

Jafarzadeh, N., Kadkhodaie, A., Ahmad, B. J., Kadkhodaie, R., and Karimi, M., 2019, Identification of electrical and petrophysical rock types based on core and well logs: Utilizing the results to delineate prolific zones in deep water sandy packages from the Shah Deniz gas field in the south Caspian Sea basin. Journal of Natural Gas Science and Engineering, v. 69, pp. 102923.

Kadri, I.B., 1995, Petroleum Geology of Pakistan. Pakistan Petroleum Limited. Ferozsons, Pvt. Ltd, 275 p.

Kazmi, A.H., 1979, Active fault systems in Pakistan. 1n: Farah, A., and DeJong, K.A. (Eds.), Geodynamics of Pakistan. Geological Survey of Pakistan, Quetta, pp. 285-294.

Kazmi, A.H., and Jan, M.Q., 1997, Geology and Tectonics of Pakistan. Graphic Publishers, ISBN 969-8375-00-7, 5C, 6/10, Nazimabad, Karachi, Pakistan, $554 \mathrm{p}$.

Kazmi, A.H., and Rana, R.A., 1982, Tectonic map of Pakistan. Geological Survey of Pakistan, Quetta. Scale 1:2,000,000.

Khan, A.A., Farid, A., Akhter, J., Munir, K., Small, J., and Ahmad, Z., 
2016, Geomorphology of the alluvial sediments and bedrock in an Intermontane Basin: Application of variogram modeling to electrical resistivity soundings. Surveys in Geophysics, v. 37, pp. 579-599.

Khan, M.J., and Khan, H.A., 2018, Petrophysical logs contribute in appraising productive sands of Lower Goru Formation, Kadanwari concession, Pakistan. Journal of Petroleum Exploration and Production Technology, v. 8, pp. 1089-1098.

Krois, P., Mahmood, T., and Milan, G., 1998, Miano field, Pakistan a case history of model driven exploration. Proceedings of the Pakistan Petroleum Convention, Islamabad, PAPG Pakistan, pp. 111-131.

Mode, A.W., and Aniyam, A.O., 2007, Reservoir characterization: Implications from petrophysical data of the "Paradise-Field", Niger Delta, Nigeria. The Pacific Journal of Science and Technology, v. 8, pp. 194-202.

Munir, K., Iqbal, M.A., Farid, A., and Shabih, S.M., 2011, Mapping the productive sands of Lower Goru Formation by using seismic stratigraphy and rock physical studies in Sawan area, southern Pakistan: a case study. Journal of Petroleum Exploration and Production Technology, v. 1, pp. 33-42.

Musawi, J.M., and Jawad, M.A., 2019, Study of different geostatistical methods to model formation porosity (Cast study of Zubair formation in Luhais oilfield), IOP Conference Series: Material Science and Engineering. doi:10.1088/1757-899X/579/1/012031

Osinowo, O.O., Ayorinde, J.O., Nwankwo. C.P., Ekeng, O.M., and Taiwo, O.B., 2018, Reservoir description and characterization of Eni field Offshore Niger Delta, southern Nigeria. Journal of Petroleum Exploration and Production Technology, v. 8, pp. 381-397.

Quadri, S.V., 1986, Hydrocarbon prospects of southern Indus Basin. Pak. AAPG Bulletin, v. 70, pp. 730-747.

Quadri, V.N., and Shuaib, S.M., 1986, Hydrocarbon prospects of southern Indus Basin, Pakistan. AAPG Bulletin, v. 70, pp. 730-747.

Sen, M., 2006, Seismic Inversion. Society of Petroleum Engineers, Richardson, $49 \mathrm{p}$.

Shamo, B., Asa, E., and Membah, J., 2012, Linear spatial 591 interpolation and analysis of annual average daily traffic data. Journal of Computing in Civil Engineering, v. 29, p. 04014022.

Singh, V., Yemez, I., and Repsol, J.S., 2013, Integrated 3D reservoir interpretation and modeling: Lessons learned and proposed solutions. The Leading Edge, v. 32, pp. 1340-1353.

Soleimani, M., Shokri, B.J., and Rafiei, M., 2016, Integrated petrophysical modeling for a strongly heterogenous and fractured reservoir, Sar-

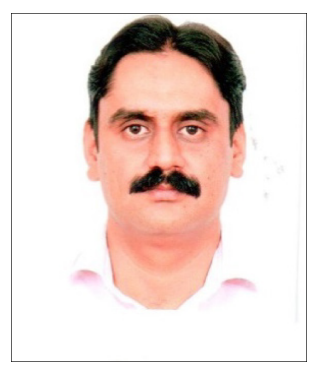

Aamir Ali Currently working as Chairman/ Associate Professor in the Department of Earth Sciences, Quaid-i-Azam University (QAU), Islamabad, Pakistan. He has obtained his PhD degree in Geophysics from University of Bergen, Norway in 2011. He has completed 07 national and international projects and published in many journals of international repute recognized all over the world. He has supervised/produced 45 MPhil and $03 \mathrm{PhD}$ students in different geosciences disciplines.

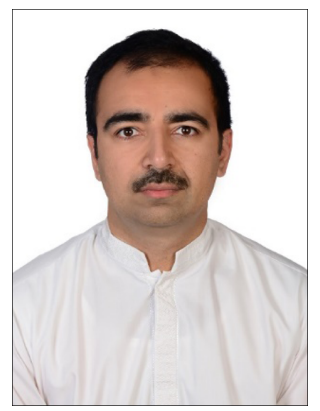

Asam Farid has done masters in Geophysics from Quaid-i-Azam University, Islamabad, Pakistan in 2005. He started his career as a geoscientist in LMKR Pakistan in 2005 and later worked in The Petroleum Institute of Abu Dhabi and Fugro Middle East, Abu Dhabi during 2008-2019. He joined geophysics department as Technical Head in ACES, Khobar Branch, Saudi Arabia, in February 2019. He has received a Ph. D degree in Geophysics from University of Punjab, Lahore, Pakistan in April 2019. vak Formation, SW Iran. Natural Resources Research, v. 26, pp. 75-88.

Tiab, D., and Donaldson, E.C., 2004, Petrophysics. Gulf Professional Publishing, Burlington, $889 \mathrm{p}$.

Toqeer, M., and Ali, A., 2017, Rock physics modelling in reservoirs within the context of time lapse seismic using well log data. Geosciences Journal, v. 21, pp. 111-122.

Vail, P.R., 1987, Seismic stratigraphy interpretation using sequence stratigraphy: Part 1: Seismic stratigraphy interpretation procedure. Atlas of seismic stratigraphy. In: Bally, A.W.(Ed), AAPG Special Volumes, AAPG Studies in Geology, v. 27, pp. 1-10.

Visser, C.A., and Viota, J.L.S., 2017, Introduction to the Groningen static reservoir model. Netherlands Journal of Geosciences, v. 96, pp. s39s46.

Williams, M.D., 1959, Stratigraphy of the Lower Indus Basin, West Pakistan. Proceedings of the $5^{\text {th }}$ World Petroleum Congress, New York, pp. WPC-1089.

Wu, X., Caumon, G., 2017, Simultaneous multiple well-seismic ties using flattened synthetic and real seismograms. Geophysics, v. 82, pp. IM13IM20.

Yasin, Q., Du, Q., Ismail, A., and Shaikh, A., 2019, A new integrated workflow for improving permeability estimation in a highly heterogeneous reservoir of Sawan gas field from well logs data. Geomechanics-Geophysics-Geo-Energy-Geo-resources, v. 5, pp. 121-142.

Zaigham, N., and Mallick, K., 2000, Prospect of hydrocarbon associated with fossil-rift structures of the southern Indus Basin, Pakistan. AAPG Bulletin, v. 84, pp. 1833-1848.

Zeng, H., and Hentz, T.F., 2004, High frequency sequence stratigraphy from seismic sedimentology: Applied to Miocene, Vermilion Block 50, Tiger Shoal area, offshore Louisiana. AAPG Bulletin, v. 88, pp. 153-174.

Zhao, Qian, Hongtao Zhu, Qianghu Liu, and Weizhong Gao., 2020, Using seismic microfacies to identify tidal sand ridges from high-precision three-dimensional seismic reflection data: An example from Xihu Depression, East China Sea Shelf Basin. In Society of Exploration Geophysicists, Technical Program Expanded Abstracts, pp 1253-1257, doi:10.1190/ segam2020-3427523.1

Zhou, F., Shields, D., Tyson, S., and Esterle, J., 2018, Comparison of sequential indicator simulation, object modelling and multiple-point statistics in reproducing channel geometries and continuity in $2 \mathrm{D}$ with two different spaced conditional datasets. Journal of Petroleum Science and Engineering, v. 166, pp. 718-730.

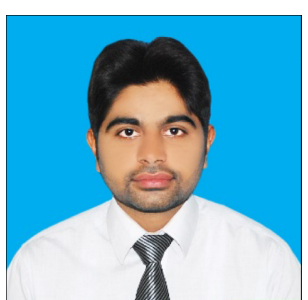

Taimoor Hassan Currently working as Associate Geoscientist in LMKR, Islamabad, Pakistan. He has obtained his M. Phil degree in Geophysics from Quaid-i-Azam University (QAU), Islamabad, Pakistan. 